\title{
SACRED SPACE,
}

\section{TIMELESS TIME:}

\section{REALITY AND THE EXISTENCE OF HANG TUAH}

\author{
Lalita Sinha \\ lalitasinha@yahoo.com
}

School of Education, Languages and Communications

Wawasan Open University

\begin{abstract}
What is real? Perhaps it lies in the concrete and tangible evidence of the existence of a person, or the occurrence of a historical event (or the profane dimension of reality). Yet intangibles (or the sacred dimension of reality) such as what we believe and what we feel are equally valid bases of our reality. Focusing on possibilities about the existence of Hang Tuah, warrior par excellence of the Malay world, the essay addresses issues of reality and existence. Initially, definitions of what is "real" and "reality" are explicated. Subsequently, drawing on Mircea Eliade's ideas on the sacred and profane dimensions and based on hermeneutical principles of interpretation, the discussion explores the possibility of the existence of Hang Tuah. The discussion moves from a literal understanding (the text), to the literary language of Hikayat Hang Tuah (the subtext), to metaphysical considerations (the metatext). The essay presents a viewpoint of a traditional Malay society which participates in a sacred universe. Using the secular view as counterpoint, the essay explores different dimensions of time and space in the spiritual reality of Hang Tuah. It concludes that in order to constitute a holistic view of reality, both the corporeal and the incorporeal dimensions are necessary.
\end{abstract}

Keywords: Hang Tuah, Malay traditional worldview, myth, reality, sacred universe, spiritual viewpoint 
Malay literature has an oral heart and voice ... this language illustrates a certain aesthetic, of harmony ... a person who knows the text intimately and in depth would be able to get to the heart of the matter and the song of its soul.

Muhammad Haji Salleh

\section{INTRODUCTION}

In a secular and scientific context, empirical evidence determines the reality and truth of a certain phenomenon or person. While empiricism is acknowledged as a valid basis for establishing truth in certain contexts, it is not the only means to obtain certainty about things in the world. Nor is "concrete" evidence entirely infallible. Historical or written evidence is not entirely objective, or for that matter, as factual as one might wish to believe. Certainly if a historian were to discover a document stating that Hang Tuah was born on a certain date in a certain place, the truth of that document would be subject to scrutiny as to its authenticity and source. Similarly, if an archaeologist were to unearth a particular grave with an inscription marking it as the site of Hang Tuah's burial it would be thoroughly researched for validation. Therefore, scholars and the lay person who subscribe to the secular view, and who declare that only empirical evidence is admissible, should consider that empirical evidence has been acknowledged, time and again, to be subjective, inconclusive, personal or even spurious. On the other hand, if, in a pragmatic environment of concretes, facts and evidences, the truth about something cannot be conclusive, what then in the matter of the spirit, dealing with abstraction, fiction and emotion? Just as one can find tangible evidences, one can unlock intangible truths with the key of understanding, discernment and wisdom. Undeniably both dimensions and levels of reality are part of, and integral to, humankind.

From such a position, and with a view to maintain a balance between concretes and abstractions as opposing perspectives of the nature of truth and validity, this essay dwells on the issue of reality, and on the truth of the existence of Hang Tuah, warrior par excellence of the Malay world by many sociological, literary and historical scholars. Specifically with reference to the quotation above, we wish to discover what is the "the heart of the matter and the song of the soul of Hang Tuah", someone purported to have lived before there were historical "evidences".

The "scientific" view appears to acknowledge only one level of reality, namely the concrete or the tangible. Yet the very fact that we are human entails 
that our existence is constituted of a spectrum of levels of reality beyond the physical: the emotional, the psychological, the spiritual dimensions, are all established fields and disciplines of inquiry into the human being, and constitute valid domains of human existence. Furthermore, this spectrum includes myth as traditional endorsement and as "evidence" of certain truths about reality. In the same context, to discover whether a person is "real", a holistic perspective that includes the "corpo-real" and the "incorpo-real", in the particular traditional milieu of the persona, might provide insights into the reality and the existence of the persona.

Often Hang Tuah has been dismissed as a romantic, mythical or imaginary figure of the Malay ethos. To argue for the legitimacy of his existence this essay begins by considering literal definitions of "real" and what constitutes "reality". To this end, denotative meanings and linguistic implications will be taken into account. Subsequently the discussion will draw on the authoritative ideas on myth and legend of Mircea Eliade, world renowned anthropologist and theoretician. This will be supplemented by a broad description of the hermeneutical principles of understanding and interpretation of texts. Discussion on the texts on Hang Tuah begins with a brief outline of the Malay worldview of antiquity. This is followed by a textual analysis based on words, phrases, ideas and beliefs from two texts, namely, Hikayat Hang Tuah (1997), (henceforth HHT) a Malay classic chronicling the exploits of Hang Tuah. Also presented are extracts from The Epic of Hang Tuah (2010), which is an English translation of HHT. It is considered as an authoritative translation since it was translated by Muhammad Haji Salleh, a National Laureate of Malaysia. Finally, certain conclusions are drawn from the discussion and the textual evidences.

Principles relating to various levels of reality, from literal and surface meanings, to literary expressions and their implications, and to metaphysical levels of reality, which relate to the representations of Hang Tuah form the basis for the attempt to establish that he is not only a reality, but as indicated in the title of this essay, he is a timeless reality who participates in a sacred space.

\section{DEFINITIONS AND PRINCIPLES OF UNDERSTANDING REALITY}

In speaking of "reality" in this essay two issues are involved: firstly, does Hang Tuah "exist" at all? And secondly, if he does then what is the nature 
of his existence? In other words, is Hang Tuah real, and if he is, what is his reality based on? The present tense is deliberately used in this regard to indicate the implication in the main title of the essay, that is, something that is real exists as a continuous and permanent reality. Therefore, temporality and use of the present tense may be seen as representative of a cyclical and repeated reality, frequently referred to by mystics as "the Eternal Now".

A dialectical approach is adopted to derive answers to the issues raised above, based on several premises. The first is that a holistic view of the reality of Hang Tuah would involve both the relative and absolute dimensions. Besides, there is a tension or opposition between two interacting elements of reality. ${ }^{1}$ The opposition lies between the relative and the absolute or between relative (or contingent) reality referring to the physical world, and absolute (or necessary) reality which is the metaphysical dimension of reality. A further premis of the arguments is that contingent (earthly) reality is of a lower order which mirrors or reflects the necessary (or Divine) reality. This idea has been expressed in the aphorism, "as above, so below." Additionally, the understanding of necessary reality, being of a higher order and thereby different from contingent reality, entails that relative values or measures of contingent reality cannot be wholly applicable to the absolute dimension.

\section{DENOTATIONS - WHAT IS REAL?}

In order to validate and substantiate the need for a holistic view it is useful to start with basics, that is, to understand denotative meanings. Definitions of the words "real" and its derivative, "reality", are useful in determining how far Hang Tuah fulfils denotations of what is real. The following paragraphs present a brief survey and discussion of the Oxford and Webster definitions for an informed view of the semantic range and scope of these two words. In the following discussion, the numbers in brackets after the definitions indicate individual denotations and associated senses of the words to facilitate reference.

The first Oxford definition of the adjective "real" is "actually existing as a thing or occurring in fact" (1). It is interesting to note that this definition is counterpoint to anything that is "not imagined or supposed" (2). Several questions may be raised in this connection, such as, what are the premises to define "actually" and "existing" and "fact"? Similarly, who would determine what is "imagined" or "supposed"? For example, between 
concretes such as a rose, and a bludgeon and abstractions such as love or pain is it correct to say that only the concretes are real and the abstractions imagined? One may be seen as a correlate or representation of another, and therefore they are both real. Therefore, abstractions are not imagined or supposed, they do "occur in fact", except that they are not "things", but feelings or emotions or qualities. For these reasons the dictionary definitions (1) and (2) are not as entirely denotative as one might assume. The point is that, if the premis of a definition is not clear, how does one accept it as entirely right or absolute or comprehensive? This shows up the differentiation between absolute and contingent values or measures, which incidentally, are both considerations in arriving at an accurate definition of a word or idea. Thus the Oxford denotations of "real" lack clarity.

Next, "real" as an adjective is also defined as, "used to emphasize the significance or seriousness of a situation" (3). In this instance, the significance and situation of Hang Tuah and the reality he represents may be substantiated as follows. It has been claimed that Hang Tuah is used to emphasize the beliefs or convictions of a vast majority of the Malay world (known locally as Nusantara), that is, an average of 350 million people of the human population. This represents a significant number, thus Hang Tuah is real according to definition (3). Additionally, the region of "the Malay world" is well-known, ${ }^{3}$ to authoritative figures of the western world, and thereby, his existence is significant to the rest of the world. This means, it is taken seriously. Nusantara is variously referred to as "the East Indies" (by the British colonial office), "South East Asia" or "the Malay Archipelago" (by Georges Cœdès, archaeologist and historian), and in authoritative chronicles of scientific exploration of the region (by British naturalist Alfred Russell Wallace), published as The Malay Archipelago. From the literary world, Joseph Conrad was greatly impressed with The Malay Archipelago, and used it as source material for some of his greatest classics, including Lord Jim. Besides, by any literary standards, the success of The Malay Archipelago may be easily verified by its repeated publications. ${ }^{4}$ Therefore, on the basis of definition (3), Hang Tuah is real.

Furthermore, the long-standing "out of Africa" theory on the origin of the human species has lately been challenged by the "out of Southeast Asia" hypothesis. Based on recent archaeological evidences from the region, the contention is that firstly, the human species originated in Southeast Asia, and secondly, this occurred in a much earlier time, putting the clock back by several thousand years, thereby shifting this all-important point in the 
development of the human species to the Malay world. Thus in the definition of real as "significance or seriousness of a situation" this emphasizes the significance of the Malay world. On one hand, much archeological "hard evidence" has been provided to support this contention. Yet, the evidence is not universally acknowledged as being conclusive. The point being made here is for the imperative need for consideration of who, and which factor(s) or measures determine the absolute truth about something or someone.

Another sense of "real" in the Oxford dictionary is in the philosophical context, "relating to something as it is, not merely as it may be described or distinguished" (4). This may be stated simply as the truth or the heart of the matter about something. In addition, still in the same context, real is defined as "existence that is absolute, self-sufficient, or objective, and not subject to human decisions or conventions" (5). This idea may also be associated with other definitions such as, "not imitation or artificial; genuine", and "true or actual" (6). Besides, "real" also applies in the attributive sense of being "proper" and "complete" (7). Such attributes and the foregoing philosophical aspects of the real are presented at length in relation to Hang Tuah's existential reality further on in this essay.

Besides the Oxford definitions, one may consider also those of the Merriam-Webster Dictionary. ${ }^{5}$ The definition of "real" as "of or relating to fixed, permanent, or immovable things" (8) corresponds to the persona of Hang Tuah in the sense that he (i.e. a "thing") has remained a permanent and fixed idea in the minds and the ethos of the peoples of Nusantara over many centuries. However, since this definition is also confined to "things", the same argument against definition (1) above applies here.

Similarly, the following definitions of the Merriam-Webster Dictionary overlap and correspond with those of the Oxford Dictionary as previously discussed: "not artificial, fraudulent, or illusory, genuine, being precisely what the name implies" (9); "occurring or existing in actuality" (10); having objective independent existence (11); "fundamental, essential"; "concerned with or containing real numbers" (12). As will be seen in the subsequent parts of the essay, these are all applicable to Hang Tuah.

An additional semantic sphere of "real" in the Webster definition that is applicable in the validation of Hang Tuah's existence and reality, is in the definition, "relating to practical or everyday concerns or activities" (13). It is well-known that Hang Tuah is seen as a template of behaviour in numerous ways that relate to beliefs and practices in the daily lives of traditional Malay society. In fact, this template is also applicable to human 
communities since they relate to universal ideals, virtues and positive traits. Thus generally or specifially, locally or globally, in time and in space, Hang Tuah qualifies as "real". Apart from definitions (1) and (8), which are limited to things, and definition (2), the premis of which may be questioned, most of the denotative meanings in the Oxford and Webster dictionaries of "real" discussed so far may be regarded as "evidence" of the "fact" that Hang Tuah is "real".

If modern western-oriented, scientific records and impressions are sufficient to establish qualitatively the significance of Hang Tuah (considered synonymous to the Malay race by the Malays themselves), then his significance can be measured as valid in quantitative terms too. For example, the importance of the numbers of the Malay races alone as mentioned above, is evident. Moreover, the time span of centuries that he has occupied their minds and captured their imaginations is also a valid measure of his significance. Essentially then, with regard to dictionary definitions and so-called objective records, the significance of Hang Tuah cannot be dismissed. In this context it may be said that, Hang Tuah "exists", and is "real".

\section{DISTINCTION OF THE SACRED AND THE PROFANE}

In the perspective of traditional or primordial societies, the world (or creation) is a hierophany, that is, a manifestation of the sacred. In other words, it is a "revelation of an absolute reality, opposed to the non-reality of the vast surrounding expanse" (Eliade) ${ }^{6}$ According to Eliade, there is a sharp distinction between what he terms as "the sacred" and "the profane" dimensions of reality. These correspond to the religious and non-religious spaces or spheres of experience. The human being conforms and contours himself to the inherent structure and order of this sacred dimension, and the pattern of behaviour, or the way humans are to conduct themselves within the sacred space, is derived from this structure. In the Islamic tradition, to which the classical Malay worldview/Hang Tuah conforms, this idea of hierophany is expressed in the Qur'anic notion of Signs (aya') of the Creator or the Divine Presence on earth/in the universe. Furthermore, in terms of presence of the sacred or divine, the universe is the macrocosm, of which humankind is a microcosm.

Closely related to the foregoing idea of sacred space is the idea of sacred time, that is, the age of origins (creation). This is explained by 
Eliade as the time when the sacred first appeared, establishing its structure in the world. It was during this time that myths originated. Myths describe creation and the primordial events that made society and the natural world what they are. Whereas in the modern, secular understanding a myth commonly refers to something which is fictitious and/or fabricated, Eliade espouses the view of traditional societies in which myth represents the absolute truth. In such a worldview, all myths relate to origins. Furthermore, traditional societies believe that the power of a thing lies in its origin. In this context the very telling phenomenon of contradictory senses of "myth" is cause for reflection: in the traditional, religious understanding a myth is the measure of authenticity and validation of truth, and in the modern understanding it is the reverse, something that is fictitious, "imagined" or "supposed".

Eliade associates the traditional view with a focus and importance only on beginnings. This means that in the traditional perspective, there is no value attached to the linear progression of historical events. According to Eliade, these peoples felt a need to return to the Beginning (or sacred time) at regular intervals, turning time into a circle. Thus the "cyclic" vision of time in ancient thought is related to belief in the eternal return. He postulates this as the reason for man's "nostalgia for origins" that appears in many religions as the desire to return to a primordial Paradise. Also, in order to give value to life, traditional societies perform myths and rituals, or what he calls "archetypes", to re-enact and re-actualize the events of the beginnings, thereby participating in the sacred. Eliade suggests that the abandonment of mythical thought and the full acceptance of linear, historical time is one of the reasons for modern man's anxieties, afflictions and general sense of disquiet. ${ }^{8}$ The re-enactments also create a sense of time standing still, or at least, "time does not hurry as the the times did not require such a pace" (Muhammad, 2011). Thus traditional societies escape this anxiety to an extent in their disavowal of historical time. The foregoing ideas of traditional reality constituting a sacred universe will be exemplified by the traditional Malay reality in an ensuing section of the essay.

\section{HERMENEUTICAL PRINCIPLES OF UNDERSTANDING AND INTERPRETATION}

Certain hermeneutical principles of understanding may enhance interpretation of what is expressed in any form of text. In fact, these are 
necessary in order to do justice to the fullness of a text. The following paragraphs briefly present some principles of hermeneutics, focusing on ideas proposed by prominent philosophers of hermeneutics. ${ }^{9}$

InTruthand Method(1989), Gadamerargues that truthorcomprehension is the result of a dialogic process that involves consciousness and factors of environment and history. He dismisses the absolute authority of the mind or ratio (L.) as a superstition, based on the view that truth or comprehension of anything (such as history or archaeology) cannot be seen as entirely free, objective and absolute. As explained by Md. Salleh (2009):

According to Gadamer's thinking, in every occasion of comprehension, those who comprehend cannot but commence at a historical situation or a particular environment, and this situation provides him with certain set of prejudices. Those prejudices surely originate from the tradition (literature and culture) of the knower himself. In fact, the text he is confronting is also part of that tradition, i.e., it is in an intertextual relationship with other texts that constitute that a particular tradition.

As further explained by Salleh, in the encounter between the knower and the text, the knower's own prejudices constantly face tests. By positioning himself within the tradition-whether consciously or not-the knower is constantly re-evaluating his prejudices so that he can act fairly towards his text. In this way prejudices that are no longer tenable can be isolated from those which are legitimate and productive. Gadamer refers to this engagement as the fusion of horizons, i.e., the fusion of the knower's horizon with the horizon of the text. In this fusion, the horizon of the text is appreciated by the knower, while the knower's horizon is richly broadened by the horizon of the text. Ricouer describes this as "an ultimate expansion of consciousness". Note that this it does not mean that the interpreter's horizon is submerged into the horizon of the text, but rather, it is broadened (Md. Salleh, 2009). In this regard, Blaikie (1995) explains that the interpreter is basically "becoming" an "experiencer" of the tradition that opens or reveals itself to him. In this context, hermeneutics means "bridging the gap between one's familiar world and the meaning that resides in an alien world". Thus, as most scholars of hermeneutics have emphasised, understanding is not reconstruction, but mediation (Blaikie, 1995).

The process of fusion, according to Ricouer, is accompanied by Aneignung or appropriation, which involves a desire to genuinely to make one's own what is initially alien (Sinha, 2008). ${ }^{10}$ For Ricouer, the 
interpreter has to approach a text in a specific manner for appropriation to be effective. First is an attitude of sympathy in relation to the text, and second, a suspension of the self. In the first instance, the aim is to "hear" or "see" beyond the words of a text. An important requisite in this regard is awareness of milieu of the text. That is, the interpreter's openness to the particular context of the tradition that forms the background of the text will allow the text to be revealed to the interpreter. In this regard, Gadamer (1989) says:

Interpretation ... does not refer to the sense intended, but to the sense that is hidden and has to be revealed. The involuntary expression(s) ..., like everything else, need explication, i.e. to be understood not only in terms of what they say, but of what they bear witness to.

To achieve this, it is important to look beyond what is said in the everyday meaning of the language, to what is being taken for granted in the originating tradition of the text. In allowing the text to reveal itself, the anteriority of the text, or what stands "in front" of it, comes into play. This notion of anteriority is explained in Ricouer's words (1986) as:

Ultimately, what the reader appropriates is a proposed world, which is not behind the text, as a hidden intention would be, but in front of it as that which the work unfolds, discovers, reveals. Henceforth, to understand is to understand oneself in front of the text. It is not a question of imposing upon the text our finite capacity of understanding, but of exposing ourselves to the text and receiving from it an enlarged self.

Ricouer also recognizes that appropriation, and ultimately appreciation and acceptance, is enabled when the nature of the interaction between the self and the text "ceases to appear as a kind of possession, (and) implies instead a moment of dis-possession of the narcissistic ego". In this context an important contrastive differentiation is held between "self" and "ego," whereby it is the text, "with its universal power of unveiling, which gives a self to the ego."

With regard to the attitude of suspension of the self, appropriation is also underpinned by an awareness of the interpreter of his own deep-seated assumptions, prejudices, or horizon of meaning, with regard to the nature of the experience or the object being studied. Without the encounter between the self and the text, pre-conceived notions would otherwise remain unknown or ignored. Awareness, and subsequently a relinquishment, of 
prejudices, brings about a suspension of presupposition and judgment, as well as a critical self-consciousness and ultimately, a transformation or metamorphosis. In this case metamorphosis is understood as a relinquishment of the self as it were, by the interpreter, to the objective guidance and support of the text. Subsequently, a genuine understanding is achieved, not only of what is written, but also of himself as a part of the meaning of the text.

It is equally important to be aware that the subject matter of the text is answering a particular question. Therefore, rather than attempt an "objective" interpretation, it is the responsibility of the interpreter first to reconstruct the question that the text is answering, and subsequently, to engage in a conversation or dialogue about it. For both Gadamer and Ricouer, dialogue involves dialectics, whereby all contradictions and conflicting forces that come into play have to be worked out in the process of investigating the truth.

\section{METHODOLOGY AND SCOPE OF DATA}

The text of the English translation of HHT by Muhammad (2011) is extensively referred to and quoted for exemplification. However it was necessary to also refer to Kassim Ahmad's original Malay text (1997) to obtain a comprehensive overview of the text. In this connection, the Malay Corpus Project (MCP), ${ }^{11}$ was invaluable. Initiated and organized by Ian Proudfoot to facilitate the study of classical Malay literature and available online, the MCP uses this particular version of Kassim's HHT to generate concordances.

With the above concordance tool, it is possible to combine a qualitative study of words with quantitative information, i.e. number or percentages of occurrences, or word frequencies. With this purpose in mind, the text of $H H T$ was searched for specific words and associations of selected words for study in the contexts they are used. As an example, occurrences of words that are relevant to time and space that might be considered are: tempat (meaning place or location) and its frequent collocations with words such as istana (palace) and keris (traditional Malay double-edged dagger), mulia (honourable) Nabi Allah (Prophet of Allah), raja (king), provide a basis to form certain observations and associations, such as the great importance placed on space and orientation. This is because the occurrences show a preoccupation with correctness and appropriacy of place for any event, 
act or building. ${ }^{12}$ It would be ideal therefore, if intuitive and qualitative impressions were complemented with quantitative figures and statistical information. This has been the motivation for including a concordancebased approach to words and their contexts, along with the subtexts and metatexts, as will be presented in the sections that follow.

In regard to the study of words and their associations, on one hand, words with the highest frequencies do not mean they are the most important in a text. The word maka in HHT (with close to 10000 occurrences) is a case in point, which has been discussed elsewhere in this essay. On the other hand, as Proudfoot (1991) has argued, it is fallacious to assume that a common word is unimportant, "because common words can unlock both overt and latent characteristics of the text". ${ }^{13}$

\section{THE SACRED UNIVERSE OF HHT}

\section{The Traditional Malay Perspective of Reality}

Prior to analysis of the text, it is first necessary to understand its specific context or milieu. In the traditional arts, classical texts included, a performance represents a participatory ritual or event of return that is shared by both by the artist or writer and the audience or reader. Braginsky has explained the dynamics of this participation, according to Hindu poetics, as follows:

... more profound and remote purpose (of poetry) was to evoke in the reader (sahridaya, connoisseur) a special aesthetic pleasure-the bliss of the intellect-resulting in his unification with Brahman, the Absolute ... A spectator attended a drama with the intention of thinking and contemplating, not of watching something real happening.

In similar vein, Eliade states that, "in imitating the exemplary acts of a god or of a mythical hero, or simply by recounting their adventures, the man of an archaic society detaches himself from profane time and magically reenters the great time, the sacred time." 14 Similarly, in Malay performing arts, the Malay folklore (cerita rakyat) participates in an event of return. Cerita rakyat refers to a series of knowledge, traditions and taboos that have been passed down through many generations in oral, written and symbolic forms among the indigenous populations of Maritime Southeast Asia. The stories within this system of lore often incorporate supernatural entities and 
magical creatures which form parts of Malay mythology. Others relate to creation myths and place naming legends that are often inter-twined with historical figures and events. Ancient rituals for healing and traditional medicine as well as complex philosophies regarding health and disease can also be found. ${ }^{15}$

From the language of the hikayat, which is a particular classical genre of Malay folklore (HHT included), a certain ethos and worldview surfaces. The language has been described as formalized, stylized, and illustrating "a certain aesthetic, of harmony, of repetitive description" (Muhammad, 2011). Thus it serves a precise purpose of evoking and pointing to a higher order of reality constituted of the natural and the Super- and Supra-natural through a certain linguistic and literary decorum. Thus it subscribes to what is "proper" [see definition (7)]. In the same light, as has been explained in reference to Eliade's view, the human being conforms to the order of the sacred dimension and a relevant pattern of behaviour. The view, that "the Malay of the 17th century is very much slower than today's Malay. It does not hurry as the times did not require such a pace" (Muhammad, 2011), quoted earlier also applies to language.

The explanation on the classical language or perspective of the traditional Malay society in HHT opens a window to an understanding of time and space that is different from the profane view. The interrelated ideas, "sacred space" as an area of spiritual connection and experience, and "timeless time" as a period that is not recorded and does not have time markers, are powerfully evoked in HHT by the expanse and depth of certain words. The word maka for instance, while functioning as a marker of time, also has a great variance of meaning such as "because", "moreover" and "so". The word is also associated with space because it is "ever present" (Muhammad, 2011), that is, everywhere and at all times. Thus the occurrence and usage of this particular word in $H H T$ shows a convergence of the temporal-spatial boundary, as they conflate and collapse into a void, a gap. This gap is the window to understanding the fundamental mystery of the Eternal Now. It refers to the paradox of the moment which is now, which is also eternity, often referred to as "living in the mystery" in many spiritual traditions of the world. For example, in Zen Buddhism, it refers to the profound experience of satori, the capacity to see things as they are [cf. denotative meanings (1), (4) and (5)]. This is an experience that is fleeting, yet it brings enlightenment that is enduring. Likewise, the great 20 th century philosopher and theologian, Paul Tillich, speaking from the Christian tradition, said: 
If nothing were given to us except the "no more" of the past and the "not yet" of the future, we would not have anything. We could not speak of the time that is our time; we would not have "presence". The mystery is that we have a present; and even more, that we have our future also because we anticipate it in "the present"; and that we have our past also, because we remember it in the present. In the present our future and our past are ours.16

Thus in the traditional worldview of reality mirrored in $H H T$, time repeats itself, that is, it is cyclical not linear. The implications here relate to some key hermeneutical principles of interpretation as basis for understanding the issues of reality and existence in the specific context of traditional perspectives as has been explained earlier.

Three specific elements in the text of $H H T$ have been selected to substantiate the claim for the existence of Hang Tuah. The nature of this worldview is seen as holistic, spiritual and sacred, and in this essay, referred to as a "sacred universe". Although the elements are discussed individually, it will soon become apparent that these are not discrete elements in the text, but overlapping, seamless and tightly-woven into the traditional worldview. The specific elements are, first, the elements of origins and hierarchy, second, the magical and mystical elements, and third, elements relating to time and space.

\section{Origin and Hierarchy}

It has been pointed out that classical Malay literature reflects a universe centred on the sacred. True to its form, the opening paragraphs of HHT typically constitute elements that display the sacred reality. The ensuing discussion exemplifies this claim by focusing on particular features of the text. ${ }^{17}$

The work commences with mention of the Divine Names in the formulaic Islamic basmala. The mention is firstly a summoning of, as it were, an immediate presence, secondly a dedication, and thirdly a remembrance, of God, that is, "In the name of Allah the Most Merciful and Most Compassionate". It reminds the reader or audience of the precise nature and function of all artistic endeavour, and thereby evokes a specific, traditional, religious milieu. Immediately following is information on beginnings, that is, origins and precise setting: "... in the celestial Abode of the Gods from where the first rulers of the Malays originally descended." The descent introduces the King of Malacca specifically as a "God-king" in 
accordance with the ancient concept of dewaraja. In other words, a divine ruler or a king is not only divinely chosen but also according to religion as observed and practiced at the time. Therefore he is God's representative on Earth and symbolizes His Power and Majesty. And Hang Tuah, as a part of a created universe of order and harmony, is no ordinary man, but according to the text, a "mythical hero and champion of the Malays ... with exemplary loyalty which shaped his life, endowing it with purpose and meaning." The setting is accordingly embellished to portray royal grandeur, majesty and hierarchy:

In the great audience hall ... His Majesty approached his throne, attired in magnificent royal robes. On his left and his right heralds bore the magical swords of state which were inlaid with radiant jewels.

When the King speaks, all "bow in obeisance ... (and) in homage." The element of hierarchy is significantly visible: God-God-king-creation, or the natural order. Further, the people are named as sub-strata in a hierarchical structure: bentara (heralds)-menteri (ministers)-pegawai (officers) representing authority, vis-a-vis the common folk and servants. The hierarchy exists, not to merely to display or exercise power and subjugation, but rather to ensure order and harmony, each knowing his or her expected code of conduct and place in the order of things.

Next comes a key element, that of name. The king is named: "Sang Perta Dewa was His Majesty's name ... ." In the traditional worldview a name constitutes a significant noble attribute, that is, an epithet with a function. Sang which is a classical honorific reference indicates divinity, royalty or nobility, somewhat equivalent to the English usage of "Lord" or "Sire" or "His Highness". Perta may be associated with a high level of hierarchy in three ways. One, as a variation of putra, a title denoting royalty. Two, associated with perta-la/petala, indicating cosmic levels of reality, as in the well-known Malay phrase, tujuh petala langit (seven levels of heaven or seventh heaven). Three, pertala is defined as "magic vehicle", that is a celestial conduit and transportation, specified as "magic steed" (Kamus Daya, 2008). Four, associated with perta-pa, contemplation. It may also be associated with perta-ma, first or foremost. Finally, dewa is "deity", "divine", or "God". In a classical milieu, the appellations of this king, combined, could be translated as, "His Majesty the Foremost Noble Heavenly Divine One on His Magic Steed". 
A name, and its constant repetition, serves as a mechanism of reminder-equally to the bearer of the name, and to those who speak the name-of the expectations of the named. That is, to be or to conduct oneself in accordance with the qualities and attributes named. Thus a specific meaning and purpose which is mutual and reciprocal in nature has to be upheld. These dynamics contribute to hierarchy, harmony and order, with repetition functioning as a ritualistic mantra, upholding participation in the sacred by actualizing and reinforcing it. This is characteristic of a sacred universe, conveyed by ubiquitous occurrences of naming and addressing in $H H T$. In the sentence/paragraph that immediately follows the naming of the king, is the phrase, "Sang Perta Dewa knew...". That is, in addition to the mechanism and effects of repetition of name, the king's knowing or knowledge has to be, and is, befitting of his divine origin and position. The power and glory of knowing or knowledge of the god-king is apparent in the following extract:

... Sang Perta Dewa knew as a god knew, that he would beget a son, and that son would be born into the human world on Seguntang Hill, in the Island of Sumatra, where he would found an enduring dynasty of renowned Kings, who would rule the Malays to the end of time.

The entire account descends like a marvellous shower of vertical linkages through an array of hierarchical levels: a god-son of a god-human world-Seguntang Hill-Island-dynasty rule-end of time. Generally, in the scheme of genealogies, not only is there an absence of dichotomy between the celestial and the terrestrial realms and characters, but also a free and frequent, bi-directional course. Each is of a natural order, a link in the chain between the human and the divine, and each with a specific association, ${ }^{18}$ a preordained function, and source. Here too is time, mentioned in the context of creation and its end, associated with the cosmic cycle of origin or source, as well as end or destination.

The significance of hierarchy, and Hang Tuah's rigorous conformation to it, have been the topic of much scholarly discourse. Leone Nurbasari makes an interesting observation about the language in $H H T$ as reflecting the relation between loyalty and space, with the former being indicated by the latter. Her words, which are self-evident, are as follows: ${ }^{19}$

Similar to the court protocol of placing oneself in a physical location according to status, or the practice of bowing at the feet of an elder or a 
member of nobility, the language used in dialogue "locates" the speaker in a position relative to the person with whom they are speaking, such as di bawah (beneath) someone of a higher status, or junjung (place on one's head/hold up high/ revere) a gift or command from a ruler. In accordance with this concept of social hierarchy, pronouns also hold status.

Thus from beginnings, in nature as in traditional man, there is harmonious participation in a divine or sacred order. In such a context, the course of the journeys of Hang Tuah, both earthly and of the spirit, involve space and time, body and soul. The complementarities in this interaction constitute a rich source of subtexts for a whole separate study. ${ }^{20}$ Celestial beginnings (or time) and earthly travels (or space) are Hang Tuah's trajectory into a path of return to the sacred realms at the "end" of his life. But in $H H T$, this end is actually a beginning-of the spiritual life of a dervish who seeks the meaning and purpose of life itself. The statement about an end being a beginning may be reinforced by the fact that there is no depiction of Hang Tuah's death in HHT. Instead, he "disappears", yet he is believed to be "out there". In fact, "out there" is not just anywhere but in a specific location, namely, "into the forest" understood as a sacred retreat.

\section{The Magical and the Mystical}

The magical and mystical elements are understood as two parts of a whole, the sacred dimension. The parts are discussed separately to facilitate understanding, and again, are not discrete or dichotomous, but rather, fluid and bi-directional. The mystical "part" is of a higher, divine order of reality as opposed to the magical, which is related to the human order. The direction of the magical is one of ascent, associated with the human effort to connect with the divine. It is characterized by phenomena, spectacle and marvel, as will be explained subsequently. Whereas the mystical involves the direction of descent associated with Divine Grace, al-baraka (Ar.), or berkat (Malay). The nature of al-baraka is noumenal, that is, a blessing, or a truth or presence devoid of all phenomenal attributes and apprehended through the intuitive faculty and not through perceptions by the senses, and counterpoint to phenomena. Berkat emanates from a person or thing that is invested with holiness, purity and sanctity, whereas karamat (Ar.) or keramat (Malay) is the energy and power inhering the receptacle (person or thing) of this emanation. 
In the above understanding, Hang Tuah's power(s), bestowed through the grace of saints, prophets and bona fide gurus are indications of descent. His ability to uphold and control this power is accentuated by his "great deference for all kinds of knowledge" and a profound respect for "other people's languages and cultures". Hang Tuah's exemplary conduct, inhering goodness and godliness, represents ascent. This is a clear instance of complementarities, that is, between Divine Will and human effort operating in tandem. Thus, the powers of Hang Tuah place him at a supramundane level in the existential hierarchy, representative of those who participate in a sacred time and space.

The English maxim, "seeing is believing" (referring to phenomenal realities), when transposed as "believing is seeing" (noumenal realities) may point to the nature of the mystical dimension. The Malay expression, "percaya dan merasai Kebenaran (believe and feel/experience the Truth)", may be applied to the dynamics of the oral Malay story-telling genre, Cerita Lipur Lara (literally meaning tales to heal sorrows) (Kipli, Nazarudin \& Rahimah, 2013). This dynamic in Malay folk culture involves a transformation in the story-teller (penglipur lara, healer of sorrows) or the performer of the tales in traditional theatre, e.g. Tok Selampit and Awang Batil (Kipli et al., 2003). This genre of story-telling which can stretch continuously over several nights mainly centres on royalty and the palace (related to the concept of dewa raja explained previously), including a great quest guided by dreams and portents (related to the supernatural dimension) in search of a certain antidote or power (related to the magical dimension). In $H H T$ all of these factors are evident. The point being made is that in the traditional view, there is a complementarity and a symbiosis between the magical and the mystical that represent elements of a sacred universe.

Hang Tuah is not only a hero, but a super-hero in that he possesses super- or extra-ordinary powers. It is useful to consider some of these powers individually. Firstly, he possesses the gift of fluency of speech in a multiplicity of languages. To borrow a biblical expression, Hang Tuah "speaks in tongues". This extraordinary power is conferred on him in the Holy Land by none other than the Prophet Khidir, guide of the mystics (Schimmel, 1975), who tells him, "Whenever you find yourself in a situation when you do not know the language of the people, draw out (this) water ... then you shall understand all the languages of the people...". Furthermore, Hang Tuah's eloquent and multi-lingual speech is accompanied by a melodiousness of voice and magnetism of bearing that instantly captivates 
all who encounter him. There are two points of note about the phenomenon of Hang Tuah's speech. One is that it evokes origins-the mythical time when peoples of the world were not separated by language-and two, the allure of his speech (and an appropriate quality of voice to articulate speech) is associated with the unique ability of speech that sets humankind apart from all other created beings. This signifies the special position or space occupied by the human race in the divine scheme of things. Such are the noumena beyond the phenomena of Hang Tuah's speech.

Besides, Hang Tuah is also bestowed with the supernatural ability to manifest things. A well-known example from $H H T$ is the phenomenon of instantly materializing a full-grown tree from a seed. However it should be noted that his powers are not magical merely in the sense of performing conjuring tricks or illusions. Instead, throughout his life from youth to oldage, we find that this power or berkat comes from higher sources. He studies under the tutelage of spiritual masters who are channels of Grace. In the martial arts, figures like Aria Putera and Sang Persata Nala, are renowned gurus. His keris, Taming Sari is a magical and miraculous weapon bestowed by a god-king, Seri Betara (Mahyudin, 2009), his diplomatic missions, are guided by the Prophet Khidir, and finally in his old age, on the mystical path of return, he is absorbed into the folds of "forest folks", a community of orang asli, or "first peoples" in the jungles of Perak. The jungle and its inhabitants to which Hang Tuah returns, signify a return to the original pristine existence that is lost to the profane world. Thus he participates in a sacred universe when god-kings and god-men walked on the earth. Again, the observable, phenomenal setting has a noumenal significance involving sacred space and time.

\section{Space and Time}

The discussion thus far has framed a specific Malay ethos reflecting Eliade's views on the traditional perspective in an earlier section of the discussion, regarding hierophany. This ethos displays an adherence to elements that shape the nature and conduct of the traditional Malay society of $H H T$ within a sacred space. It is also evident from the foregoing examples and discussion that the narration of the event of beginnings represents, and takes place during, a sacred, mythical time. In this section specific expressions of space-time elements in $H H T$ will be the focus of analysis and exemplification.

The spatio-temporal setting of $H H T$ and the life of Hang Tuah is 
generally well known. Namely, it is Nusantara, the Malay Archipelago of a fifteenth century Malay community of Malacca. Additionally, there is a significant element of encounter with "the other" regions and peoples beyond Nusantara, from Rome and Turkey to the west, to Egypt and Makkah (or Mecca) in the Middle East, China and Japan in the far east and the southern part of the Indian subcontinent. This multicultural setting (or space) is indicative of the nature of interaction among human communities of antiquity. It is also indicative of the interconnectedness enjoyed in primordial times, and fostered by Hang Tuah's multi-lingual power as discussed previously.

The textual and the extra-textual time spans beginnings from celestial kings to the present day and to the future. According to Muhammad (2011), Hang Tuah has been present in the mind of the Malay for at least the last six centuries, and is still very much alive today as the foremost symbol of their survival. In fact it is pointed out that Hang Tuah's qualities of dedication coupled with knowledge (including knowledge of the self), and industry have created possibilities that are eternal and infinite. The well known Malay saying, Takkan Melayu hilang di dunia (the Malay peoples will never vanish from the earth), believed to be inspired by $H H T$, clearly has profound spatio-temporal implications. In the time-space continuum, it encompasses enduring connections: spatially it includes horizontal connections, i.e. between man and his environment, and vertical connections, i.e. between man and God; whereas temporally it spans the past, the present, and the future.

The narrative is linear in terms of time in a profane or secular context. In other words, the plot moves through a chronological cause-effect sequence. Yet, qualitatively, the portrayal is of a reality which is cyclical and sacred. As observed so far, from beginnings, nature functions and moves on an inexorable pre-ordained course, man aligns himself with this course, and the divine draws creation back unto itself at the end of the cycle. In brief, time is depicted in a context of harmonious participation in a sacred universe. And this is the reality of Hang Tuah.

The portrayal is reminiscent of the ancient Hindu spiritual system of the stages of human life. It begins with brahmacarya (brahma or creator as acarya, teacher and spiritual guide). It also includes the entire created universe as teacher. Spanning adolescence to adulthood, brahmacarya is synonymous to "education", that is, the stage of acquiring knowledge and practice from every available source including a guru, and moving through 
other stages, culminating in sanyasin, the renunciate, which is characterized by a withdrawal from the profane world. At this stage the domestic and the material are renounced to give place to a life of the wanderer in a hermitage or sacred grove, living out the final span of the earthly life in contemplation and inward journeys. All of these characteristics are richly in evidence in relation to Hang Tuah en route to his numerous and varied destinations.

Before ending the discussion, it may be said that the ideas forwarding the view of a sacred universe in $H H T$ could perhaps be considered as somewhat impressionistic or as a reading into the text or between the lines. Although this is a valid basis for literary analysis and for identifying subtexts and implicit meanings, it is also useful to substantiate this process through scrutiny of the internal evidences of the text. That is, words of the original Malay text of $H H T$ should be studied in their context, so as to be led by the text per se, in addition to arguments for or against a certain point of view on it. With a view to corroborate impressions formed, words in $H H T$ relating to time and space and variants of these, were picked at random and considered in their individual contexts (at the sentence or paragraph levels), so that they may "speak" for themselves. In this regard the MCP concordance tool was used to generate examples of the words selected. The words for time, in alphabetical order are: apabila (when), kala (time or period), ketika (during, while), masa (time), waktu (time), whereas those relating to space are: bumi (earth, world), halaman (vicinity), Melaka (Malacca), ruang (area, space), tempat (location). The results are tabulated and presented in Appendix 1. Furthermore, the word concordance for tempat (space or place) is also presented. A casual observance of both show that in most cases, their occurrences complement and corroborate the perspective of sacred space and time forwarded in this essay.

\section{CONCLUSION}

This essay has attempted to establish the existence of Hang Tuah by drawing on the traditional perspective of reality in general and the worldview of the Malay communities of antiquity as mirrored in the classic text of HHT in particular. It has argued for a balanced view that considers elements of both the corporeal and incorporeal dimensions of existence on forming views of what constitutes the real, and reality.

The writer has forwarded the conviction that the eternal which is sacred, is more real than the temporary which is profane, just as the view of cyclical 
time is more holistic than that of a linear time which is one-dimensional and humanly-conceived to facilitate chronological measurement. One should consider two aspects of a thing or event or person, the outward or manifest and the inward or hidden, in deciding upon its existence or reality. Although the position taken and the existence of Hang Tuah may be challenged and contested, the discussion in this essay has brought to light to the possibility of perceiving and understanding truths of the physical and the metaphysical levels of reality, or the "song in the heart" of classical texts, and particularly the existence of mythical figures, that provide a valid basis for saying that Hang Tuah is essentially real.

In closing, the following traditional aphorism, which encapsulates the viewpoint of this essay, is offered for reflection:

What is seen may not be real;

What is real may not be seen.

\section{NOTES}

1. Free Merriam-Webster online dictionary. http://education.yahoo.com/reference/ dictionary/entry/dialectic(accessed on 26 October 2012).

2. http://oxforddictionaries.com/definition/american_english/ reality?region=us\&q=reality (accessed on 26 October 2012).

3. The information on this topic is largely based on the Wikipedia entry at the following websites: http://en.wikipedia.org/wiki/The_Malay_Archipelago (accessed on 29 September). 2012)http://en.wikipedia.org/wiki/Georges_Coed\%C3\%A8s (accessed on 29 September 2012).

4. First published in 1869 in two volumes by Macmillan and Company (London) and the same year in one volume by Harper \& Brothers (New York). It was revised through 10 editions with the last published in 1890. It is considered to be one of the most influential books ever written about the Indonesian islands.

5. http://www.merriam-webster.com/dictionary/real (accessed on 26 October 2012).

6. The explanation in this section is adapted from the entry on "Eternal return". Cf. http://en.wikipedia.org/wiki/Eternal_return (accessed on 29 September 2012).

7. http://en.wikipedia.org/wiki/Mircea_Eliade\#cite_note-96.

8. http://en.wikipedia.org/wiki/Mircea_Eliade\#cite_note-97.

9. The explanations in this part of the discussion are largely based on Md.Salleh's Pilgrimage to the Orient (2009).

10. Extracted from Lalita Sinha's Unveiling the Garden of Love (2008).

11. http://mcp.anu.edu.au/ (accessed on 20 August 2012). This database of Malay classics, known as the Malay Concordance Project, comprises 165 texts and 5.8 million words (including Kassim's Hikayat Hang Tuah (1997) and is maintained by foremost scholars of Malay literature worldwide. From concordances of the digitized texts it is possible 


\section{MALAY LITERATURE}

to study the actual contexts in which words are used, and where particular terms occur in particular texts (that is, words in their textual and contextual milieu). Among the authoritative scholars involved in the MCP are, Amin Sweeney, Annabel Gallop, Henri Chambert-Loir, Jan van der Putten, Mulaika Hijjas, Titik Pujiastuti, Ulrich Kratz, Virginia Hooker and the prestigious National Universities of Australia (ANU) and Singapore (NUS).

12. See Appendix 2 for concordance generated for tempat, arranged in alphabetical order.

13. in I. Proudfoot, "Concordances and Classical Malay", Bijdragen tot de Taal-, Land- en Volkenkunde vol. 147 (1991), pp.74-95.

14. http://en.wikipedia.org/wiki/Mircea_Eliade\#cite_note-Eliade.2C_p.23-89.

15. http://en.wikipedia.org/wiki/Malay_folklore (accessed 29 September 2012).

16. http://www.octobernight.com/matrix/addendum/Tillich $\% 20-\% 20$ The $\% 20$ Eternal $\% 20$ Now.htm (29 September 2012).

17. All quotations in this section are extracted from, and based on, the observations of Muhammad Haji Salleh in The Epic of Hang Tuah (2011).

18. That is, not just a man who is king, but a dewaraja; similarly, not just any hill, but Seguntang Hill. In a purely profane or historical context Seguntang may be cited as the location of the first Malay kingdom, near what is now known as Palembang (cf. "Glossary", in Muhammad 2010, p.536). However the sacred dimension is inherent in the verticality of a hill or mountain, symbolizing its function of human-divine linkage.

19. See "The Language of Loyalty in Hikayat Hang Tuah", Leone Nurbasari (2012).

20. This has been discussed to some extent elsewhere by the present author. See Lalita Sinha, "Harmonious Echoes From the Past: An Esoteric Interpretation of Hang Tuah's Journey to India", in Sacred Web, Journal of Tradition and Modernity.

\section{REFERENCES}

Blaikie, Norman, 1995. Approaches to Social Enquiry. Cambridge: Polity Press. Braginsky, Vladimir, 2001. The Comparative Study of Traditional Asian Literatures: From Reflective Traditionalism to Neo-Traditionalism. Richmond, Surrey: Curzon Press.

Eliade, Mircea.

http://en.wikipedia.org/wiki/Eternal_return (accessed on 29 September 2012).

http://en.wikipedia.org/wiki/Mircea_Eliade\#cite_note-96-97.

http://en.wikipedia.org/wiki/Mircea_Eliade\#cite_note-97.

http://en.wikipedia.org/wiki/Mircea_Eliade\#cite_note-Eliade.2C_p.23-89.

Free Merriam-Webster online dictionary. http://education.yahoo.com/reference/ dictionary/entry/dialectic (accessed on 26 October 2012).

http://en.wikipedia.org/wiki/Georges_Coed\%C3\%A8s (accessed on 29 September 2012).

http://en.wikipedia.org/wiki/Malay_folklore (accessed 29 September 2012).

http://en.wikipedia.org/wiki/The_Malay_Archipelago_ (accessed on 29

September). 2012) 
http://www.merriam-webster.com/dictionary/real (accessed on 26 October 2012). http://www.octobernight.com/matrix/addendum/Tillich\%20-\%20The\%20

Eternal\%20Now.htm (29 September 2012).

Gadamer, Hans-Georg, 1989. Truth and Method. rev. $2^{\text {nd }}$ ed. New York: Crossroad. Kamus Daya, 2008. Seri Kembangan: Penerbitan Minda (M) Sdn.Bhd.

Kasim Ahmad, 1997. Hikayat Hang Tuah, Kuala Lumpur: Yayasan Karyawan and Dewan Bahasa dan Pustaka.

Leone Nurbasari, "The Language of Loyalty in Hikayat Hang Tuah" in http://mcp. anu.edu.au (accessed on 20 August 2012).

Mahyudin Al-Mudra (2009). "Melacak Asal-Usul Keris dan Peranananya dalam Sejarah Nusantara" in Sari 27 pp.27-44.

Malay Concordance Project. http://mcp.anu.edu.au/ (accessed on 20 August 2012).

Md. Salleh Yaapar, 2009. Pilgrimage to the Orient. Translated by Lalita Sinha. Kuala Lumpur: Institut Terjemahan Negara Malaysia.

Mokhtar Saidin, 2012. From Stone Age to Early Civilisation in Malaysia: Empowering Identity of Race. Monography Series. Penang: USM Press.

Mohd. Kipli Abdul Rahman, Nazarudin Zainun \& Rahimah A. Hamid, 2013. "Percaya dan Merasai Kebenaran: Analisis Teknik Transformasi dalam Kaedah Lakon Teater Tradisional 'Tok Selampit' dan 'Awang Batil'” in Kearifan Tempatan: Pengalaman Nusantara. Jilid 2 - Meneliti Kosmologi dan Adat Istiadat. Penang: Universiti Sains Malaysia Press.

Muhammad Haji Salleh, 2011. The Epic of Hang Tuah. Kuala Lumpur: Institut Terjemahan Negara Malaysia.

Oxford Dictionary Online. http://oxforddictionaries.com/definition/american_ english/ reality?region=us\&q=reality (accessed on 26 October 2012).

Proudfoot, Ian, 1991. "Concordances and Classical Malay" in Bijdragen tot de Taal-, Land-en Volkenkunde vol. 147 pp.74-95.

Ricouer, Paul (1986). "Composition and Interpretation" in The Relevance of The Beautiful and Other Essays. Translated by Nicholas Walker and Edited by Robert Bernasconi. Cambridge: Cambridge University Press.

Schimmel, Annemarie, 1976. Mystical Dimensions of Islam. Chapel Hill: The University of North Carolina Press.

Sinha, Lalita, 2009. Unveiling the Garden of Love: Mystical Symbolism in Layla Majnun and Gitagovinda. Bloomington, Indiana:World Wisdom Inc.

Sinha, Lalita, 2008. "Harmonious Echoes From the Past: An Esoteric Interpretation of Hang Tuah's Journey to India" in Sacred Web, Journal of Tradition and Modernity Summer 2008. 
APPENDIX 1

HHT-words denoting space and time

\begin{tabular}{|c|c|c|}
\hline $\begin{array}{l}\text { Words for } \\
\text { TIME }\end{array}$ & $\begin{array}{l}\text { No. of } \\
\text { occurrences }\end{array}$ & Examples of words in context \\
\hline $\begin{array}{l}\text { apabila } \\
\text { (when) }\end{array}$ & 130 & $\begin{array}{l}\text { 1. Maka tubuh baginda itu pun gilang-gemilanglah lantas keluar } \\
\text { dihadap oleh cahaya permata itu. Apabila baginda bergerak, seketika } \\
\text { warna kuning, seketika warna putih dan merah dan hijau, ikut seperti } \\
\text { warna permata yang terkena pada kelambu jala-jala emas dan perak ... } \\
\text { 2. Maka kata Laksamana, "Adapun firasat orang bijaksana dan } \\
\text { berani itu, apabila ada suatu tandanya gerak-gerakan dirasainya, } \\
\text { maka hendaklah barang sesuatu makanan dan minuman itu diunduri; } \\
\text { kerana segala hulubalang yang bijaksana dan berani itu, }\end{array}$ \\
\hline $\begin{array}{l}\text { kala (time or } \\
\text { period) }\end{array}$ & 37 & $\begin{array}{l}\text { 1. Maka segala negeri pada Tanah Melayu itu pun sekaliannya } \\
\text { memberi ufti ke Melaka. Maka segala pegawai dan petuanan pun } \\
\text { terlalu kasih akan raja muda, sediakala datang mengadap raja } \\
\text { dan* sediakala makan minum dengan bersuka-sukaan dengan } \\
\text { segala bunyi-bunyian. Maka segala dagang santeri pun banyak } \\
\text { datang ke Melaka itu, sekaliannya ... } \\
\text { 2. Maka sembah Laksamana, "Daulat Tuanku Andika Betara." } \\
\text { Maka Laksamana pun berceriteralah perintah segala raja-raja } \\
\text { yang dahulukala. }\end{array}$ \\
\hline $\begin{array}{l}\text { ketika } \\
\text { (during, } \\
\text { while) }\end{array}$ & 130 & $\begin{array}{l}\text { 1. Maka sembah khatib itu, "Ya tuanku, jikalau hendak berperang } \\
\text { itu pada sembilan haribulan Jamadilawal pada hari Ahad pada ketika } \\
\text { asar baik berjalan; ular alah oleh katak. Dua hari lagi." Setelah Tun } \\
\text { Megat menengar kata khatib demikian itu, maka Tun Megat pun } \\
\text { duduklah makan minum bersuka-sukaan } \\
\text { 2. Adapun patik menjadi hamba mengerjakan barang pekerjaan duli } \\
\text { syah alam daripada umur patik sepuluh tahun hingga sampai pada } \\
\text { ketika ini tiada dijanjikan Allah Taala mati dan luka. Maka ini patik } \\
\text { pun sudah tualah; biarlah patik mati dengan pekerjaan duli syah } \\
\text { alam, kerana nyawa patik ini. }\end{array}$ \\
\hline masa (time) & 12 & $\begin{array}{l}\text { 1. tuanku pun raja besar juga pada zaman ini. Patutlah kita berkasih- } \\
\text { kasihan dengan dia, supaya masyhur nama tuanku, datang kepada akhir } \\
\text { zaman disebut orang sampai pada masa anak cucu duli syah alam." } \\
\text { 2. Bermula pada masa itu hijrah Nabi Sallallahu alaihi wa-sallam } \\
\text { baharu delapan ratus delapan puluh enam tahun. Maka tatkala itu } \\
\text { anak Zainul Abidin yang bernama Syarif Ahmad itulah menjadi raja }\end{array}$ \\
\hline waktu (time) & 10 & $\begin{array}{l}\text { 1. Demikianlah istiadat baginda itu sentiasanya. Syahadan hari } \\
\text { baginda berangkat keluar pun sampailah. Daripada waktu subuh } \\
\text { maka berbunyilah genta alamat itu tujuh kali berturut-turut; } \\
\text { 2. Arkian maka datanglah pada ketika hari yang baik dan waktu } \\
\text { yang senang; maka Bendahara Mangkubumi pun menyuruhkan } \\
\text { segala raja-raja dan pegawai hulubalang pergi menyambut surat } \\
\text { dan bingkis itu dengan segala bunyi-bunyian }\end{array}$ \\
\hline
\end{tabular}




\begin{tabular}{|c|c|c|}
\hline $\begin{array}{l}\text { Words for } \\
\text { SPACE }\end{array}$ & $\begin{array}{l}\text { No. of } \\
\text { occurrences }\end{array}$ & Examples of words in context \\
\hline $\begin{array}{l}\text { bumi (earth, } \\
\text { world) }\end{array}$ & 193 & $\begin{array}{l}\text { 1. Maka dilihat oleh Petala Bumi dan Barit Ketika kelakuan Laksamana } \\
\text { dan segala pegawai bertunggu itu lambat tidur, maka Petala Bumi pun } \\
\text { menjadikan dirinya kucing dan Barit Ketika menjadikan dirinya tikus. } \\
\text { 2. Setelah datang ke balairung itu, maka dilihat oleh Laksamana } \\
\text { kuda itu kuda tinggi enam hasta dan romanya hijau seperti sayap } \\
\text { kumbang dan lakunya seperti tiada berjijak di bumi dan kelakuannya } \\
\text { kuda itu seperti singa yang galak. }\end{array}$ \\
\hline $\begin{array}{l}\text { halaman } \\
\text { (vicinity) }\end{array}$ & 19 & $\begin{array}{l}\text { 1. Maka Bentara pun menyembah lalu pergi dengan rakyat } \\
\text { mengangkut segala harta itu di Bukit China. Maka harta itu pun } \\
\text { terlalu banyak. Maka segala harta itu ditimbunkan di halaman } \\
\text { balairung itu, tujuh hari tujuh malam berangkut segala harta itu. } \\
\text { 2. Maka Bentara pun menyembah lalu pergi dengan rakyat } \\
\text { mengangkut segala harta itu di Bukit China. Maka harta itu pun } \\
\text { terlalu banyak. Maka segala harta itu ditimbunkan di halaman } \\
\text { balairung itu, tujuh hari tujuh malam berangkut segala harta itu. }\end{array}$ \\
\hline $\begin{array}{l}\text { Melaka } \\
\text { (Malacca) }\end{array}$ & 854 & $\begin{array}{l}\text { 1. Adapun pada tempat kayu melaka ini kita membangun istana } \\
\text { dan balairung dan bendul dan istana; sama tengah negeri." Maka } \\
\text { sahut Temenggung dan Pegawai, "Baiklah ini tempat istana." Maka } \\
\text { Bendahara dan Temenggung pun membangunkan istana tujuh belas } \\
\text { ruang. Maka diperbuatnya istananya itu bertingkap tujuh terlalu } \\
\text { indah-indah; } \\
\text { 2. seribu orang sertanya. Maka raja pun belayarlah ke Melaka. Berapa } \\
\text { lamanya maka sampailah ke Melaka. Maka Temenggung Sarwa } \\
\text { Raja pun naiklah ke istana. Maka dilihat baginda tempat negeri dan } \\
\text { tempat istana itu terlalu baik. Maka baginda pun terlalu sukacita }\end{array}$ \\
\hline $\begin{array}{l}\text { ruang (area, } \\
\text { space) }\end{array}$ & 14 & $\begin{array}{l}\text { 1. Maka sahut Temenggung dan Pegawai, "Baiklah ini tempat istana." } \\
\text { Maka Bendahara dan Temenggung pun membangunkan istana tujuh } \\
\text { belas ruang. Maka diperbuatnya istananya itu bertingkap tujuh terlalu } \\
\text { indah-indah; Hang Tuah yang berbuat dia tingkap itu, } \\
\text { 2. maka Laksamana pun mengerahkan orang bekerja hendak akan } \\
\text { segera sudah istana itu. Hatta berapa puluh hari lamanya maka istana } \\
\text { itu pun terdirilah tujuh belas ruang. Setelah sudah maka Laksamana } \\
\text { pun kembalilah. }\end{array}$ \\
\hline $\begin{array}{l}\text { tempat } \\
\text { (location) }\end{array}$ & 189 & $\begin{array}{l}\text { 1. sembah Bendahara Paduka Raja dan segala menteri yang tua-tua } \\
\text { itu. "Ya tuanku syah alam, ada patik dengar kata orang tua-tua patik, } \\
\text { jika ada pelanduk putih pada hutan atau barang tempat sekalipun, } \\
\text { baiklah tempat, patut diperbuat negeri; berdaulat negeri, tuanku." } \\
\text { Setelah baginda mendengar sembah Bendahara dan segala menteri } \\
\text { tua-tua demikian itu } \\
\text { 3. suatu medan terlalu luas sekali, gereseknya daripada batu } \\
\text { pelinggam, bergelar Medan Cerani dan pada sama tengah medan } \\
\text { itu sebuah gunung; di atas gunung itu menara tempat semayam } \\
\text { bergelar Kegunungan Menara Permata, tiangnya daripada tembaga } \\
\text { dan atapnya daripada perak, sisik rumbia dan kemuncaknya suasa. } \\
\text { Maka apabila kena sinar matahari }\end{array}$ \\
\hline
\end{tabular}




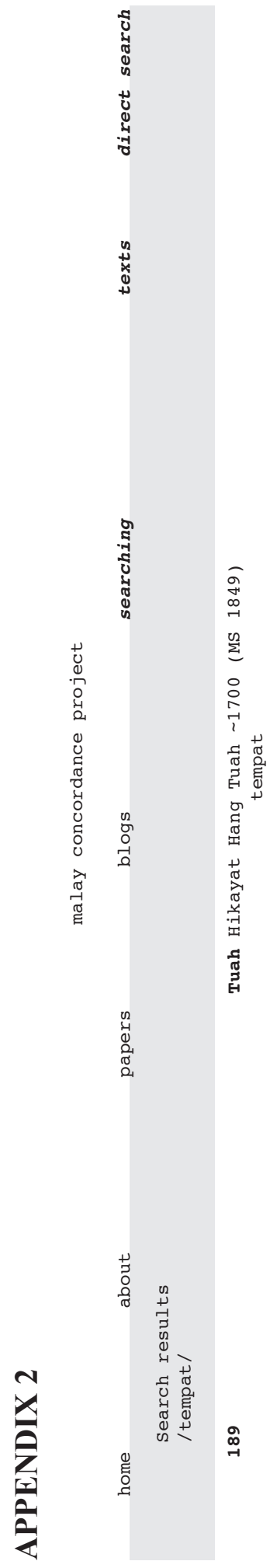

: 先 $\vdots$ ⿹ -

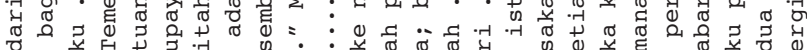
б

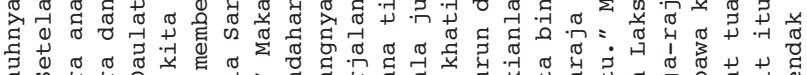

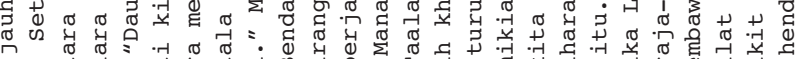

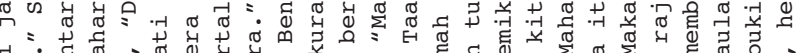

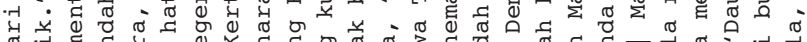

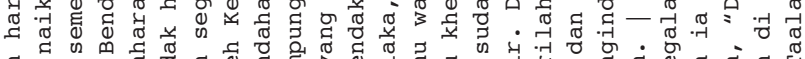
द

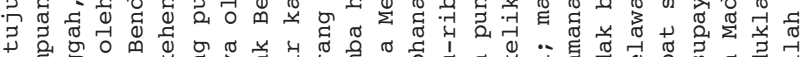
э †

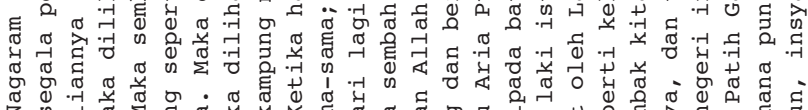

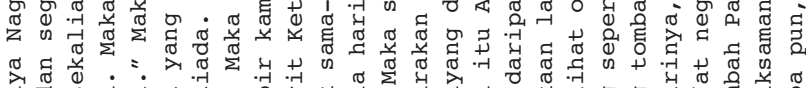

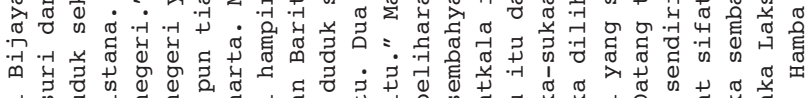

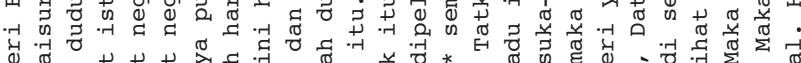
बृ

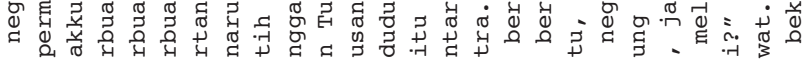

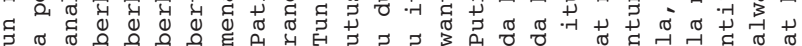

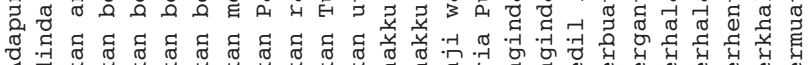
罂

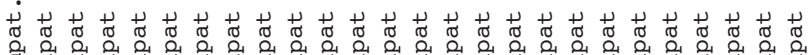

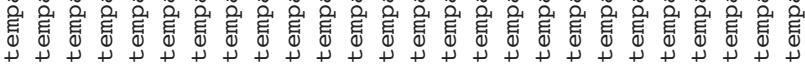

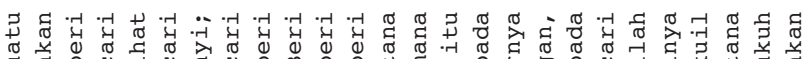
西 थ Э 泋

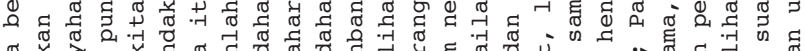

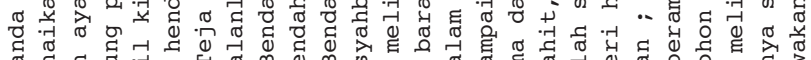

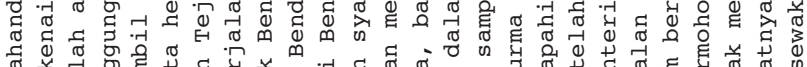

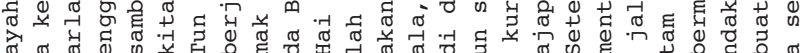

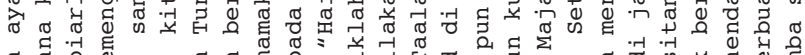

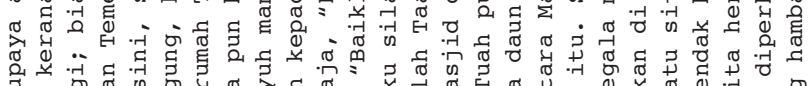

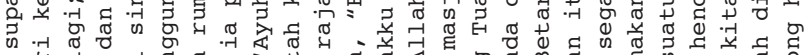

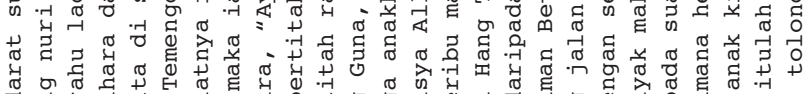
ช

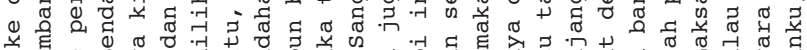

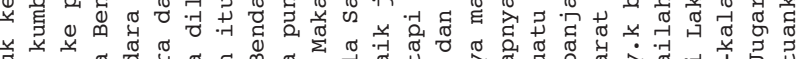
节幽

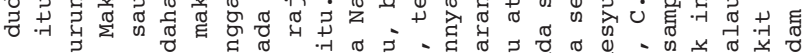
光

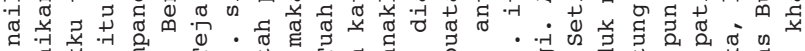
$:$ 近

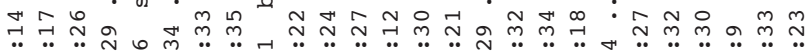

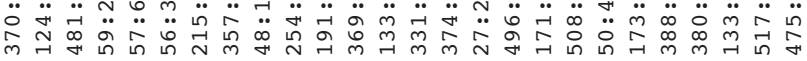

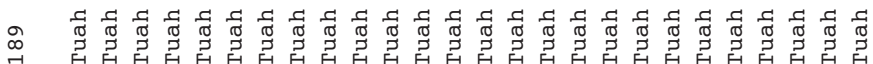




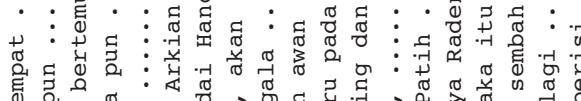

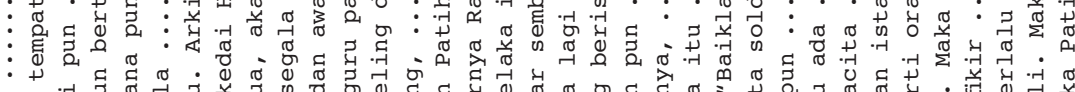

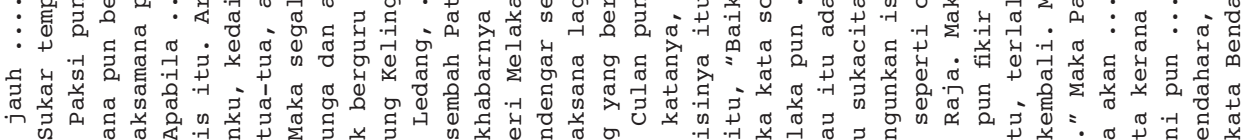

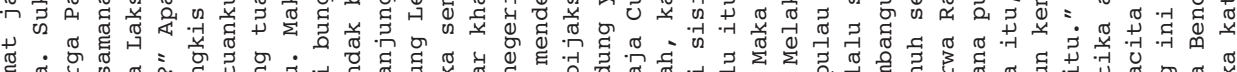
范

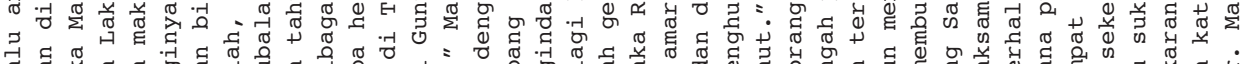

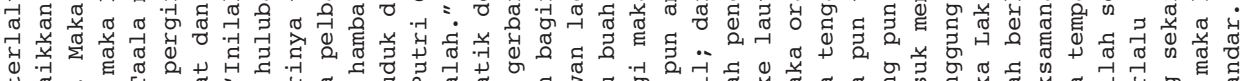
0.

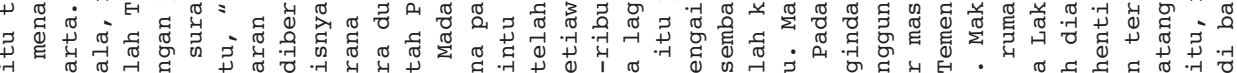

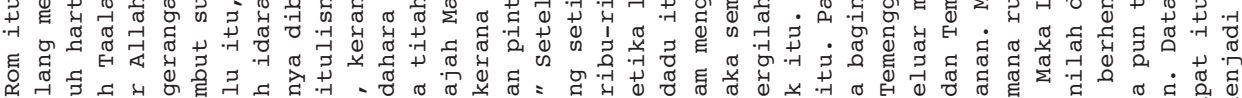
凹

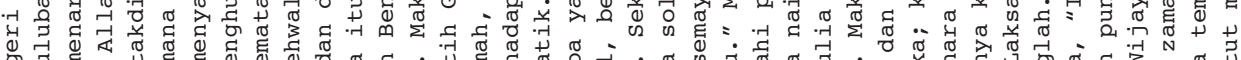
ब

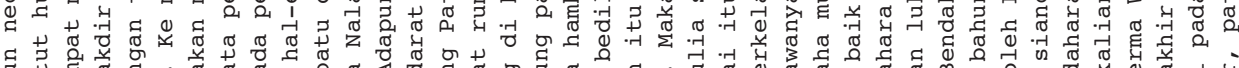
క్

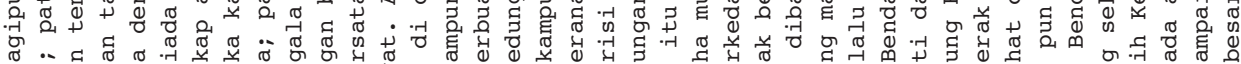
西 б. 年

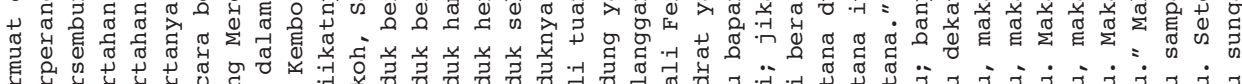
氙

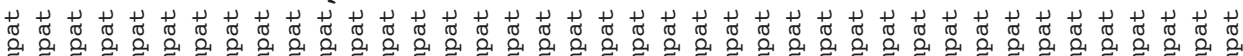

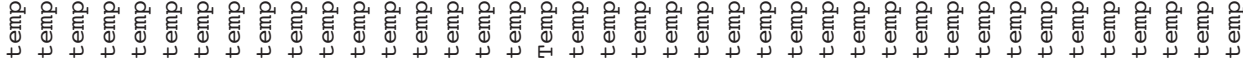

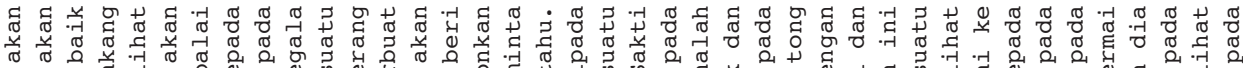

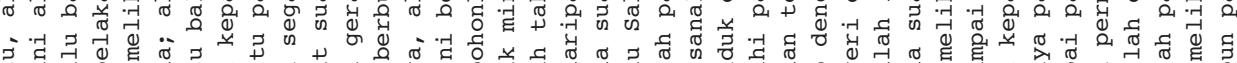

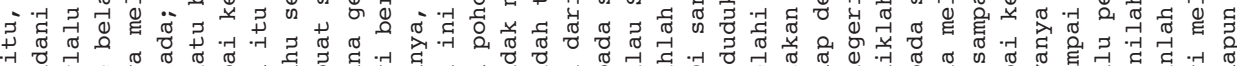
-7 芹

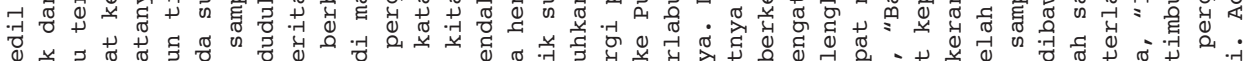
芉

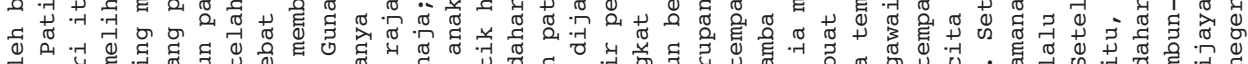

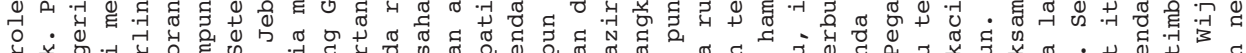

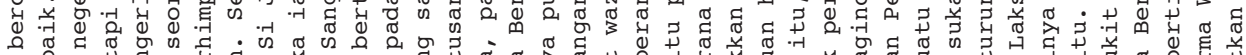
ช Q

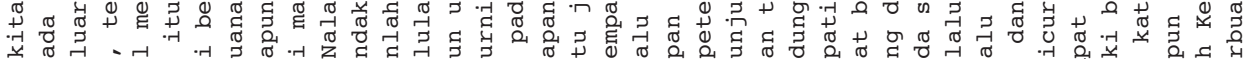

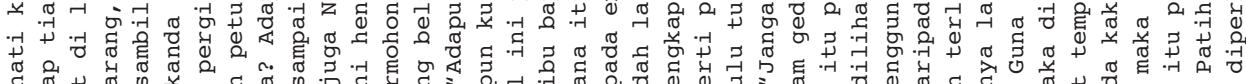

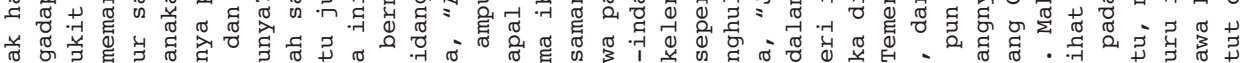

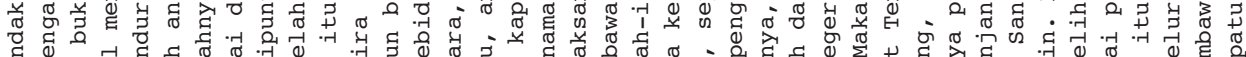

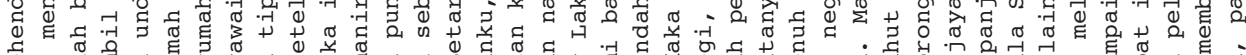

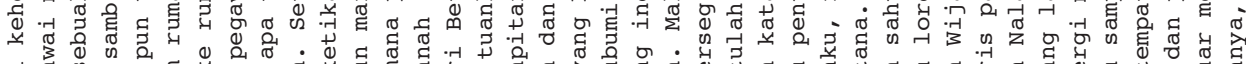

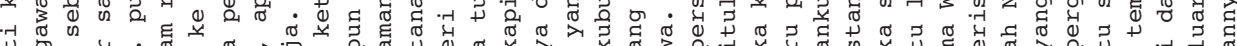
氙

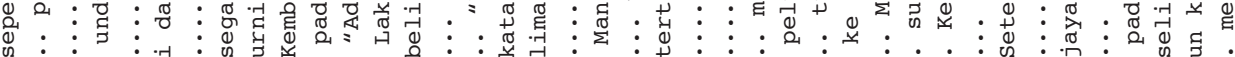

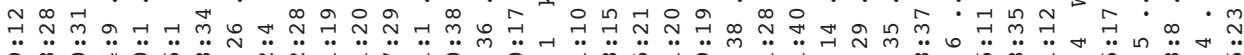

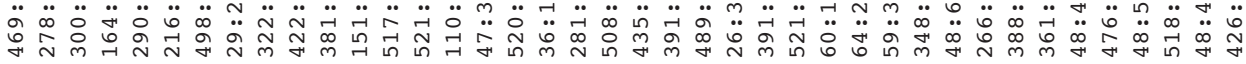
శี

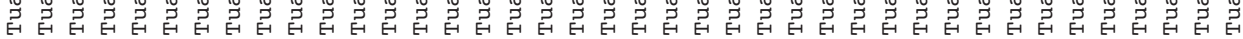




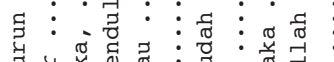

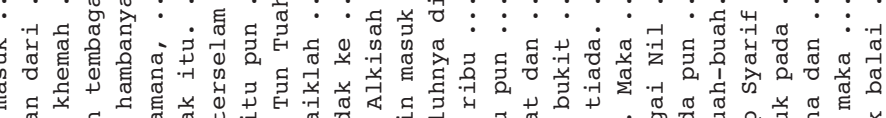

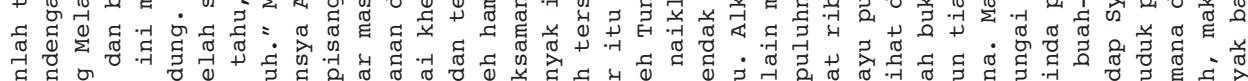

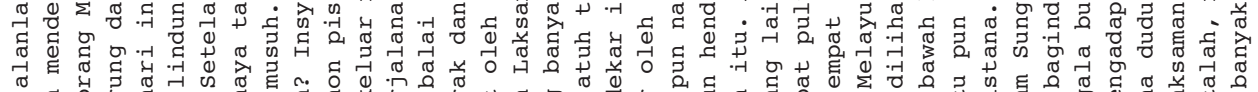

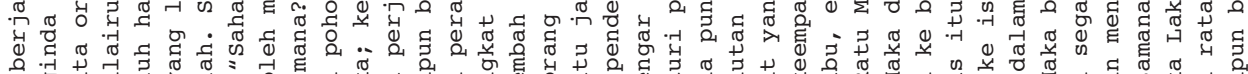

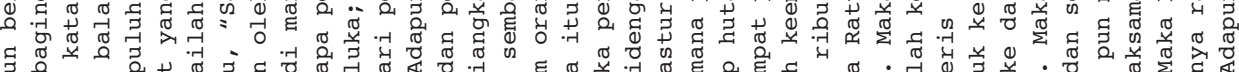

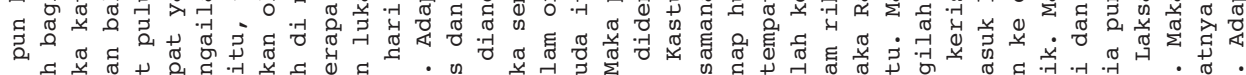

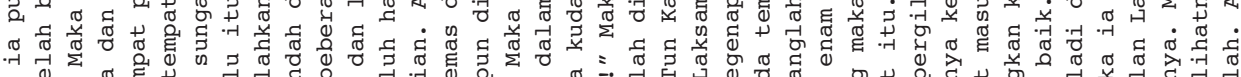

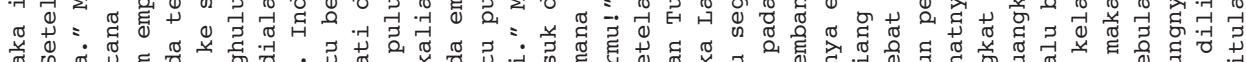

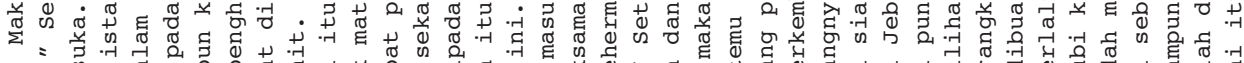

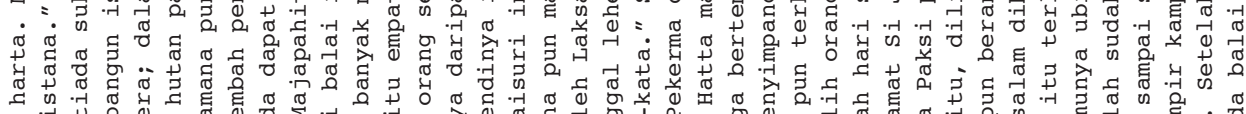

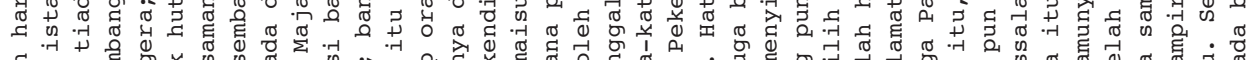

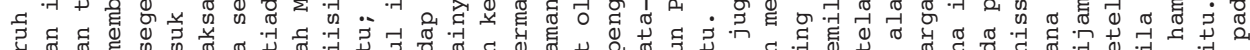

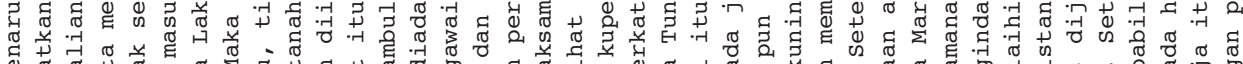

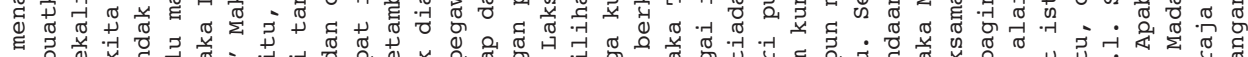

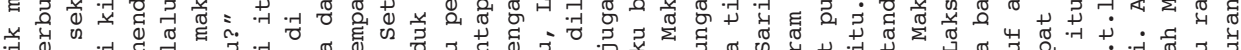

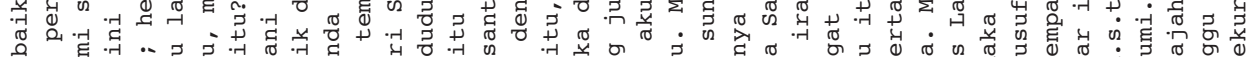

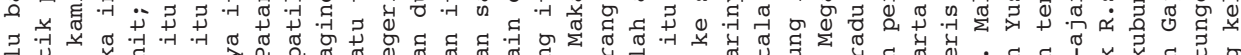

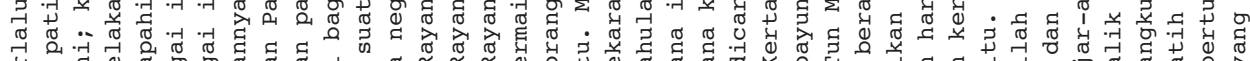

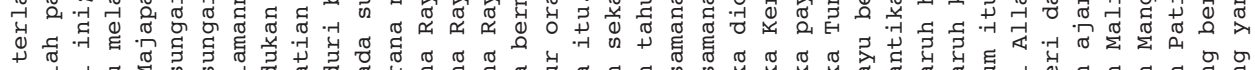

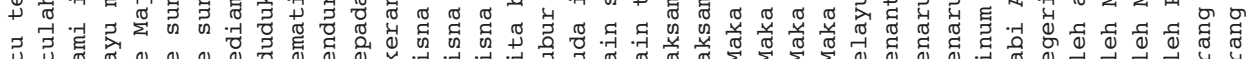

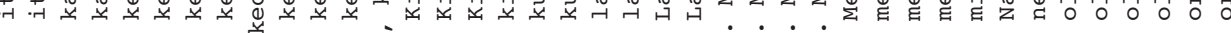

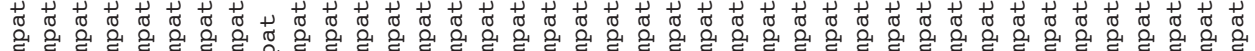

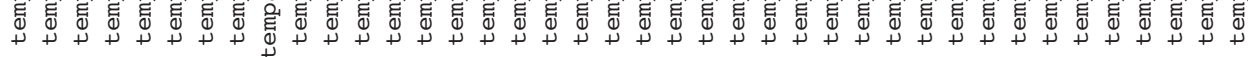

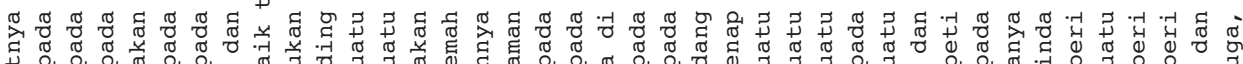

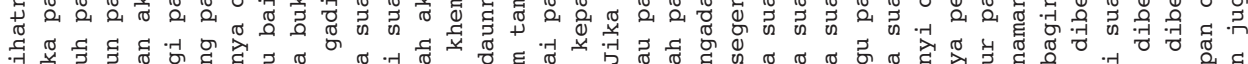

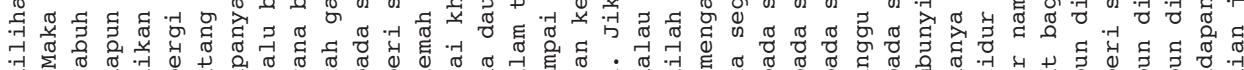
न

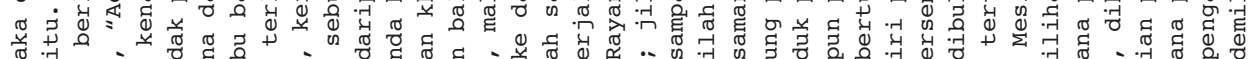
尝

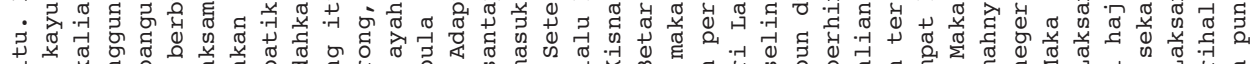

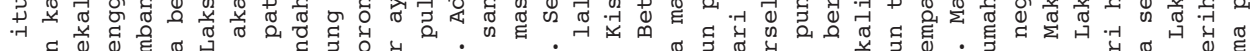

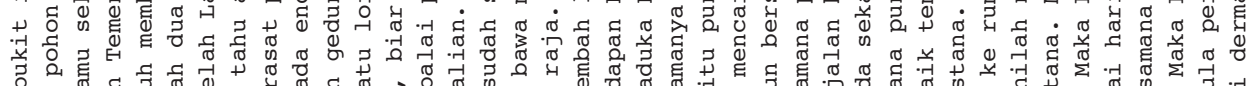

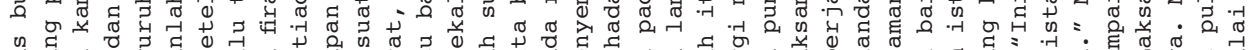

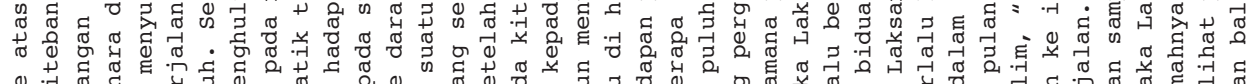

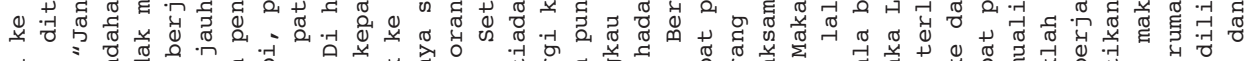

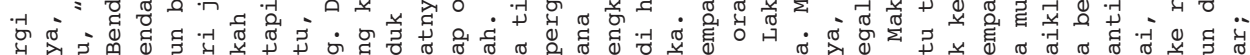

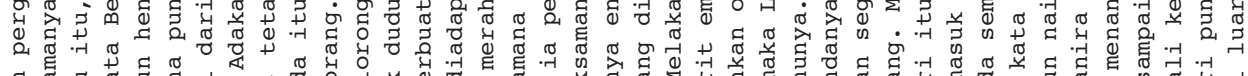

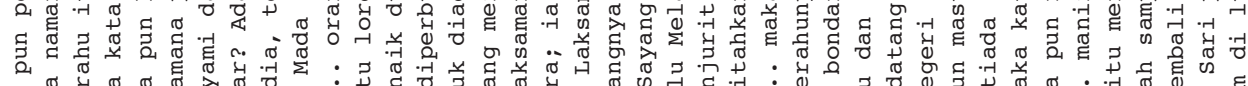

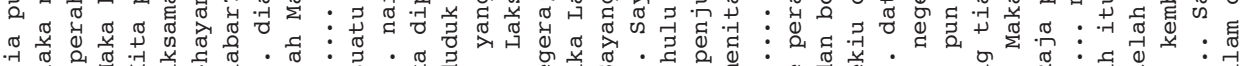
:

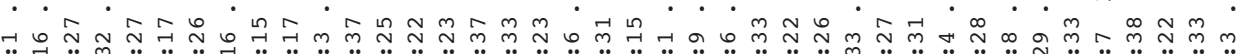

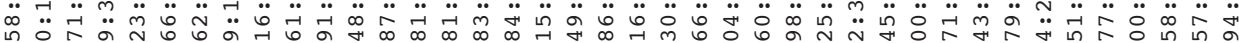

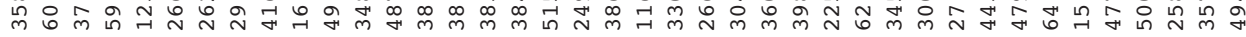

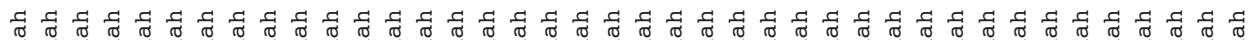

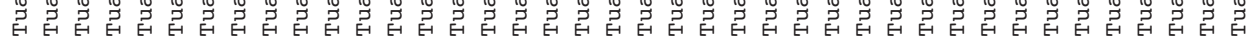




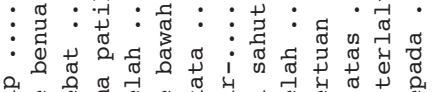

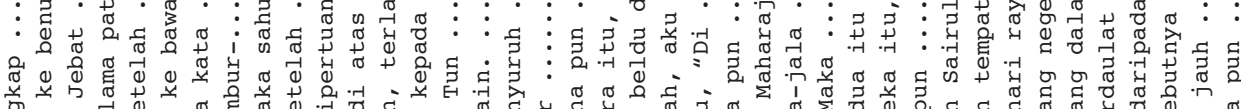

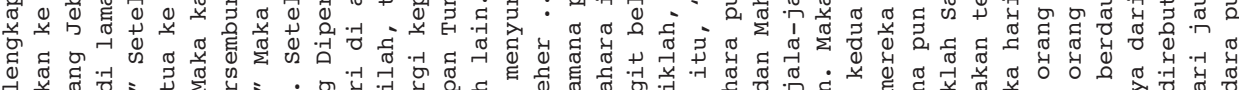

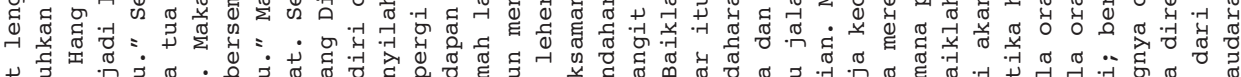

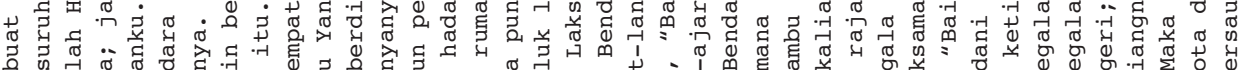
至 ब శี

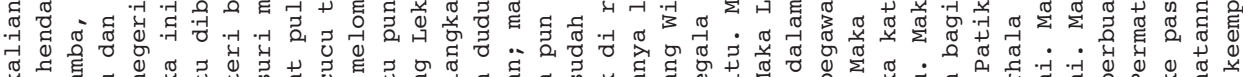

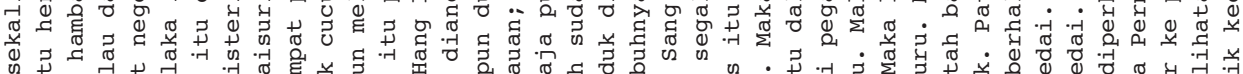
क

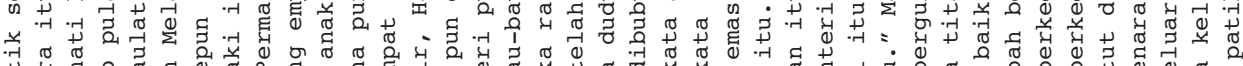

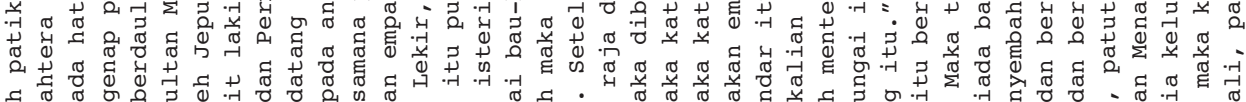
శี

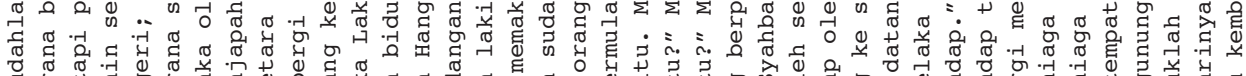

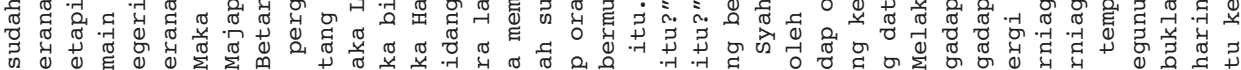

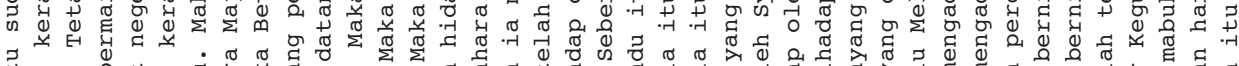

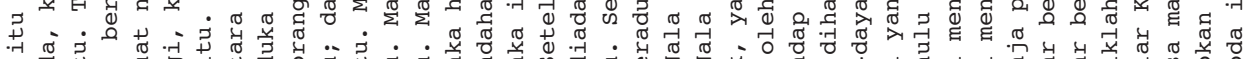

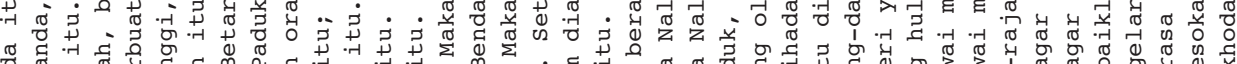

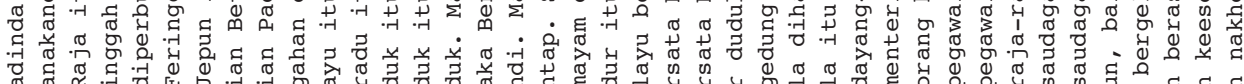

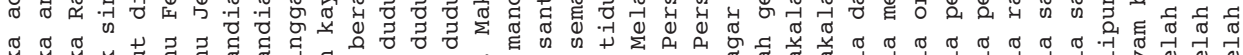

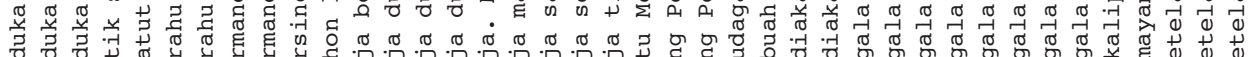

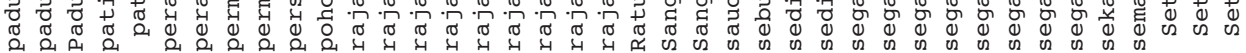

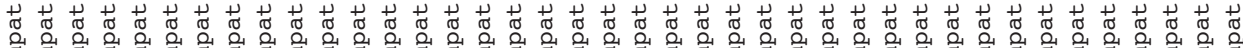

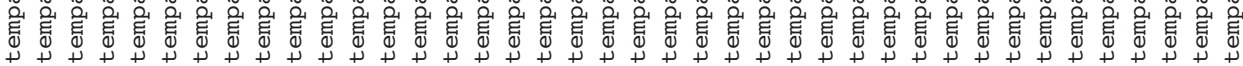

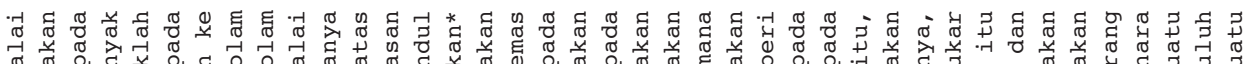
శ 药

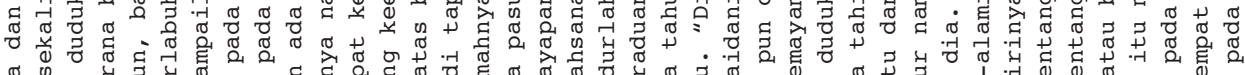

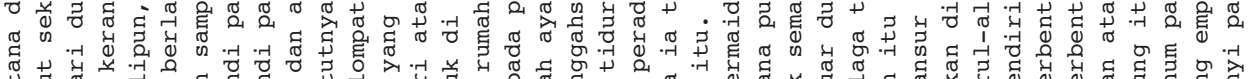

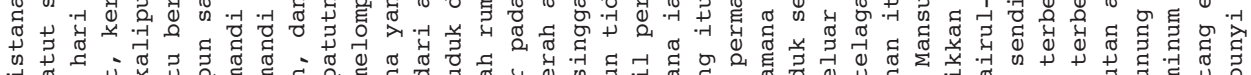

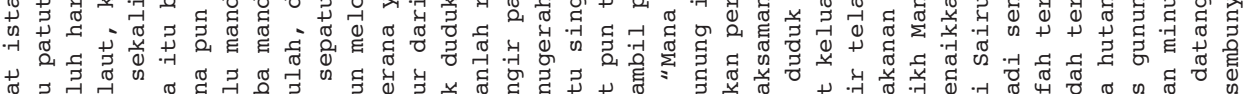

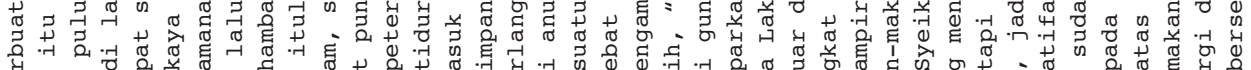
然

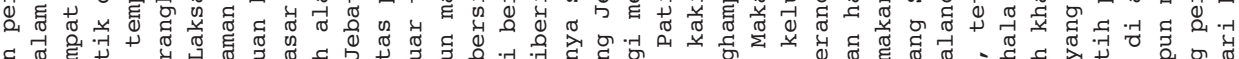

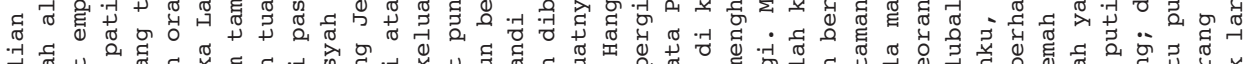

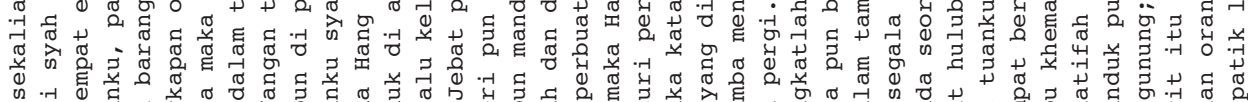

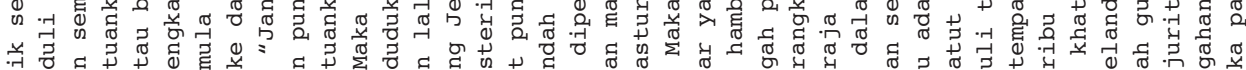

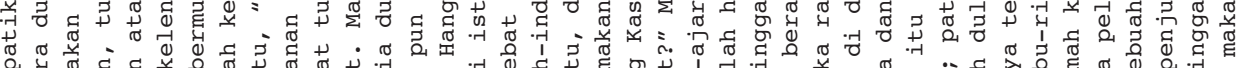
๔

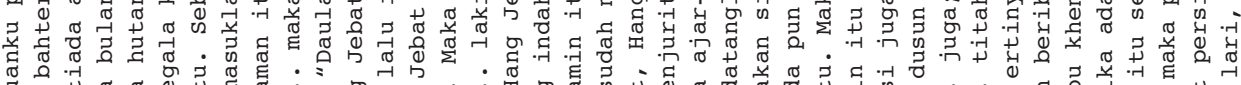

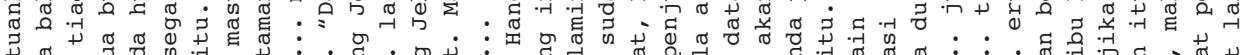

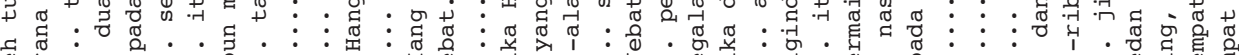
(a)

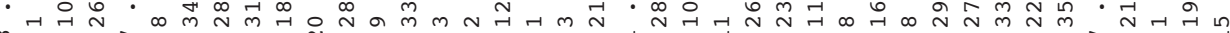

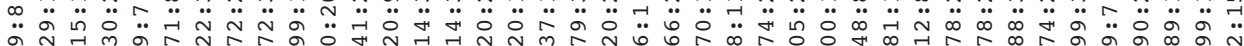

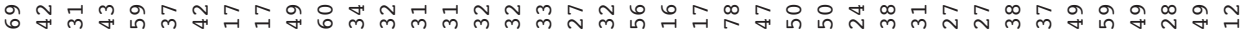
శี శี శี

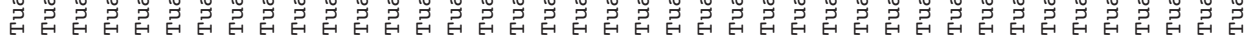




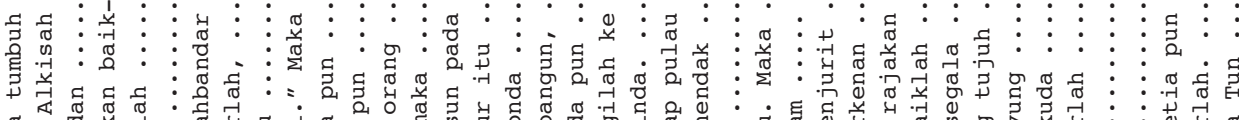
శூ †

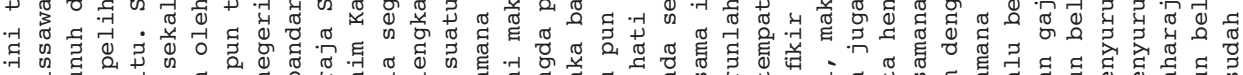

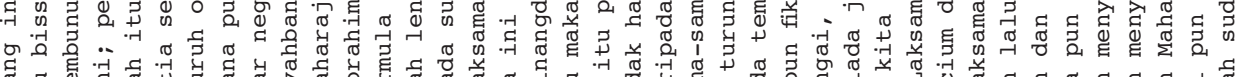

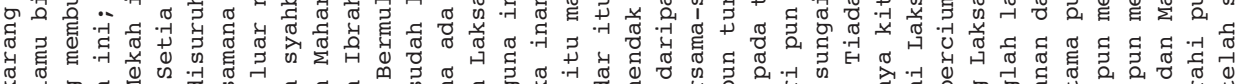
б б б 水

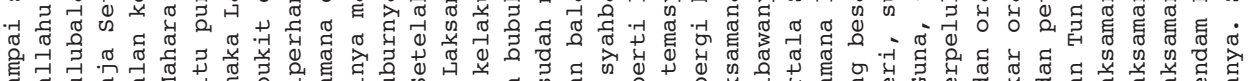

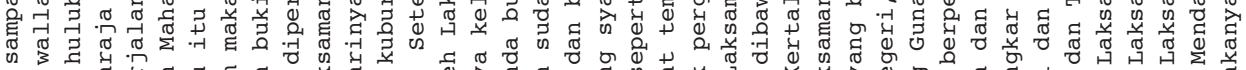

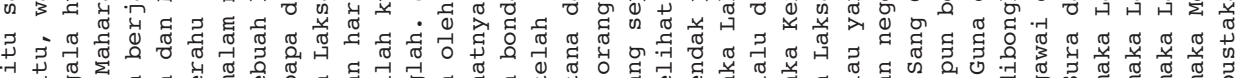

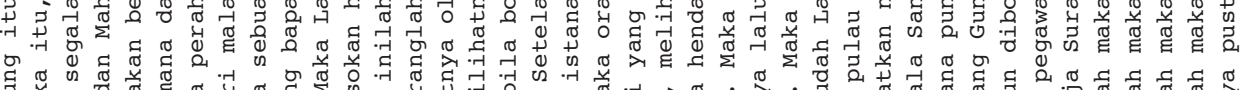

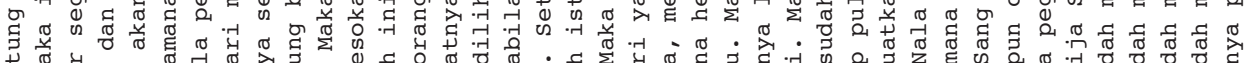

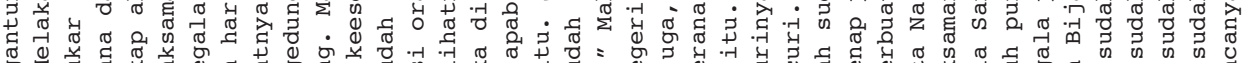

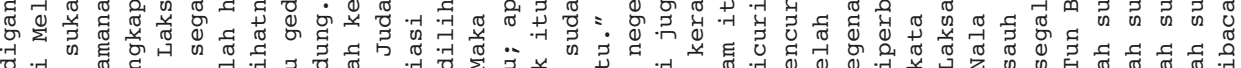
न

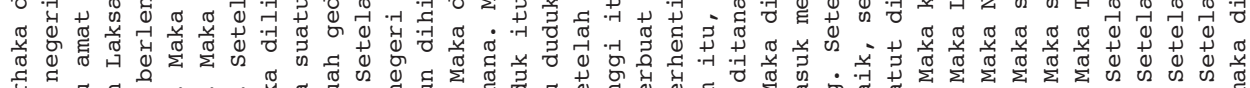

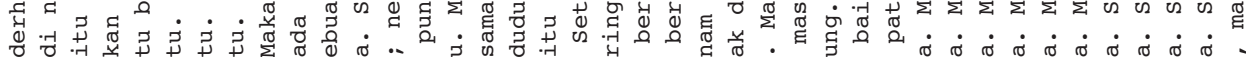
ర व

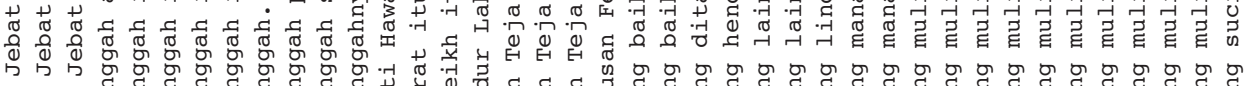

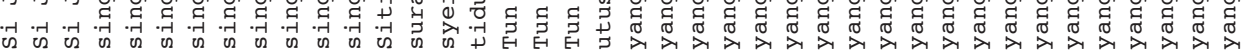

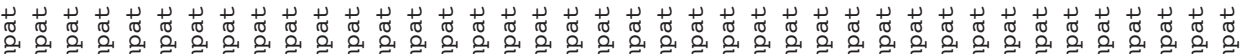

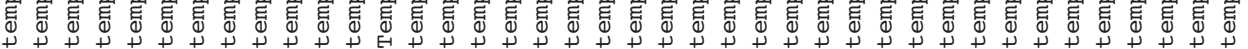
శี శే б ๘

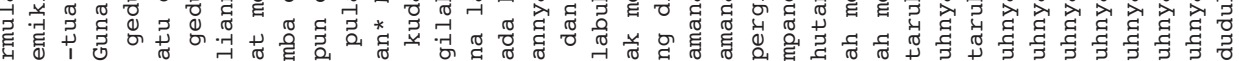

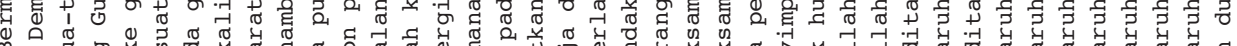
甲.

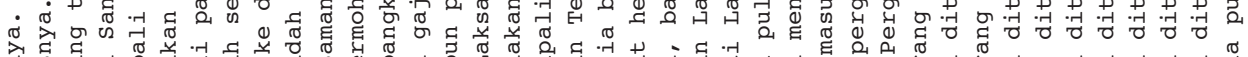
考 击

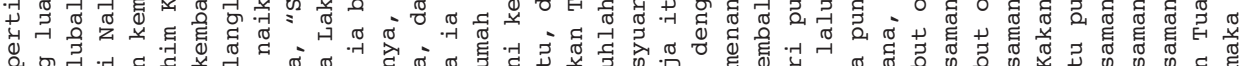

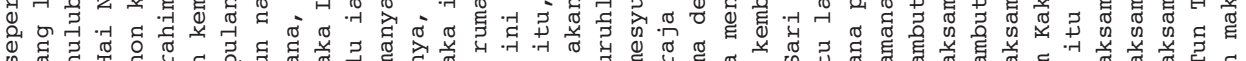

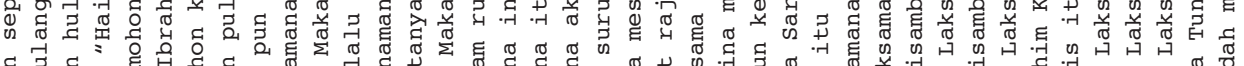

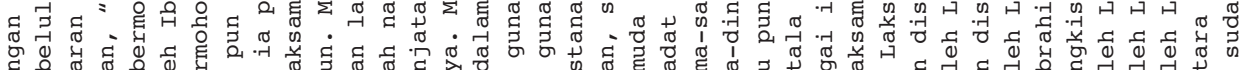

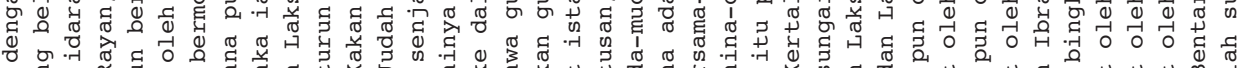
ช

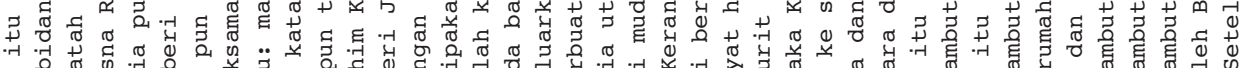

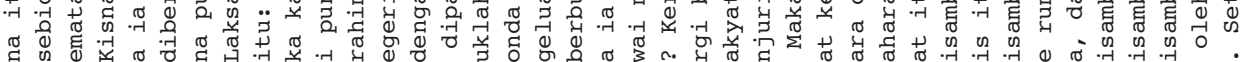

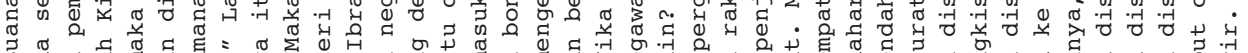

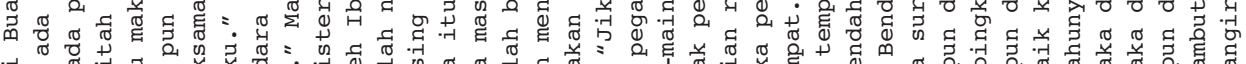

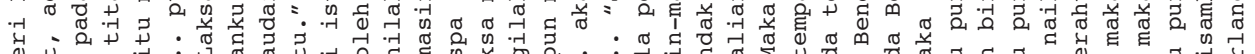

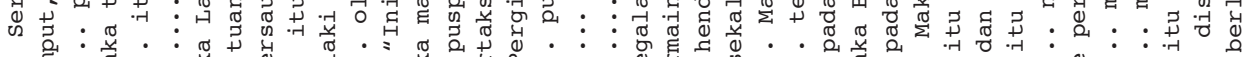

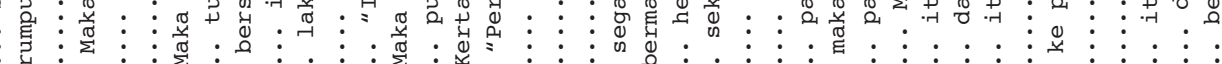

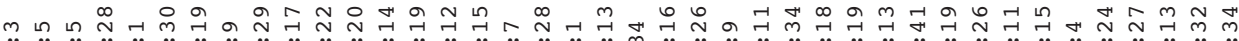

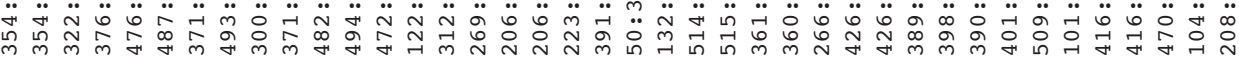

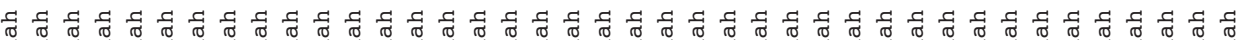

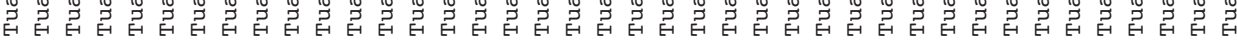

